\title{
Cyanopivaloyl Ester in the Automated Solid-Phase Synthesis of Oligorhamnans
}

\author{
Anne Geert Volbeda, Jeanine van Mechelen, Nico Meeuwenoord, Herman S. Overkleeft, \\ Gijsbert A. van der Marel, and Jeroen D. C. Codée*(i) \\ Leiden Institute of Chemistry, Leiden University, P.O. Box 9502, 2300 RA Leiden, The Netherlands
}

Supporting Information

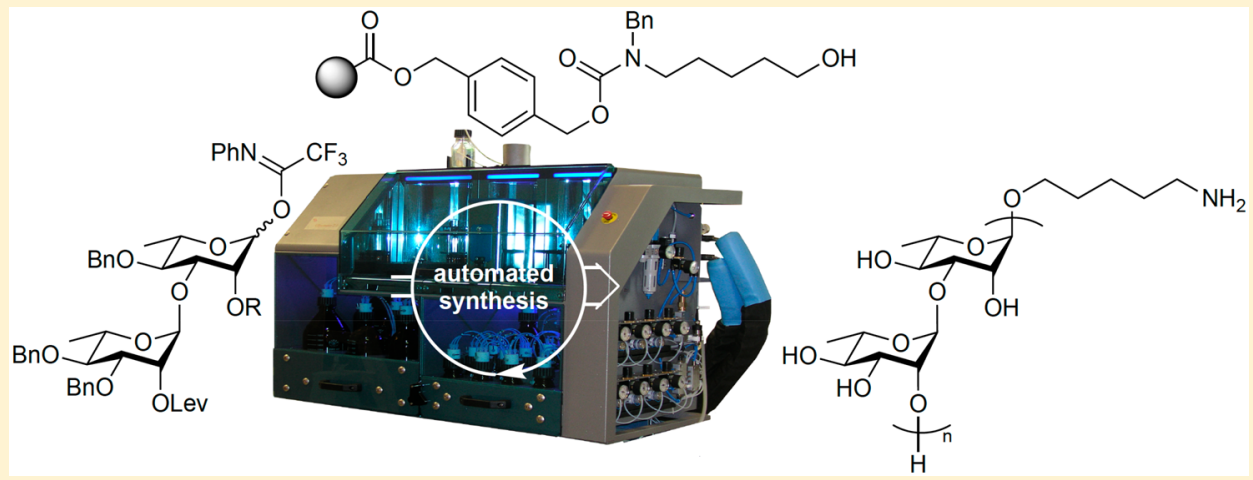

ABSTRACT: The development of effective protecting group chemistry is an important driving force behind the progress in the synthesis of complex oligosaccharides. Automated solid-phase synthesis is an attractive technique for the rapid assembly of oligosaccharides, built up of repetitive elements. The fact that (harsh) reagents are used in excess in multiple reaction cycles makes this technique extra demanding on the protecting groups used. Here, the synthesis of a set of oligorhamnan fragments is reported using the cyanopivaloyl (PivCN) ester to ensure effective neighboring group participation during the glycosylation events. The PivCN group combines the favorable characteristics of the parent pivaloyl (Piv) ester, stability, minimal migratory aptitude, minimal orthoester formation, while it can be cleaved under mild conditions. We show that the remote $\mathrm{CN}$ group in the PivCN renders the PivCN carbonyl more electropositive and thus susceptible to nucleophilic cleavage. This feature is built upon in the automated solid-phase assembly of the oligorhamnan fragments. Where the use of a Piv-protected building block failed because of incomplete cleavage, PivCN-protected synthons performed well and allowed the generation of oligorhamnans, up to 16 monosaccharides in length.

\section{INTRODUCTION}

The advent of automated solid-phase synthesis approaches for the assembly of nucleic acids and peptides has transformed the way chemists generate (fragments of) these biopolymers, and the rapid access to these molecules has revolutionized the life sciences. The automated solid-phase synthesis of oligosaccharides is significantly more complex than the assembly of the other two biopolymers, and as a result, its development has been significantly slower. Nonetheless, there has been significant progress in the field of automated solid-phase oligosaccharide synthesis over the past decade. ${ }^{1,2}$ A commercial synthesizer is now available, and there are continuous efforts to build improved machines. ${ }^{3,4}$ Ever more complex molecules are being assembled in an automated manner, and recent highlights include the assembly of libraries of plant-derived branched arabino-xylan and xyloglucan structures, ${ }^{5}$ hyaluronic acid fragments up to 15 monosaccharides in length, ${ }^{6}$ a 50 -mer polymannoside, ${ }^{7}$ a set of dermatan ${ }^{8}$ and keratan sulfates, ${ }^{9}$ a set of $\alpha$-glucans, ${ }^{10}$ and a collection of mannuronic acid alginates, built up to $12 \beta$-mannuronic acid residues linkages. ${ }^{11}$ These synthetic successes have shown that linear and branches structures can be assembled in an automated means and that both 1,2-trans and 1,2-cis linkages can be reliably installed using solid-phase chemistry. The method is especially attractive for the generation of libraries of oligosaccharides and oligosaccharides featuring repetitive elements.

The key to any successful oligosaccharide synthesis campaign is the protection group strategy used. Permanent protecting groups should be able to withstand all conditions used throughout the assembly route, while temporary protecting groups have to be removed selectively without touching any other functionalities in the molecule. The requirements for protecting groups in automated solid-phase oligosaccharide synthesis are even more strenuous as they have to withstand glycosylation and deprotection steps repeatedly, under conditions harsher than those used in traditional solutionphase experiments, because often an excess of reagents is used

Received: October 3, 2017

Published: November 17, 2017 


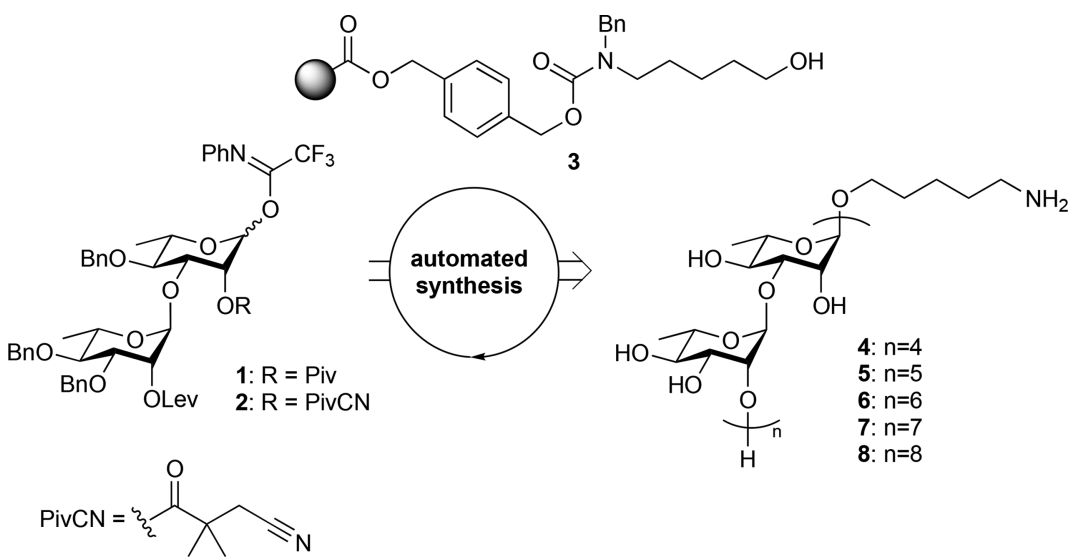

Figure 1. Synthetic approach described in this work.

Scheme 1. Generation of the Linker-Equipped Resin ${ }^{a}$

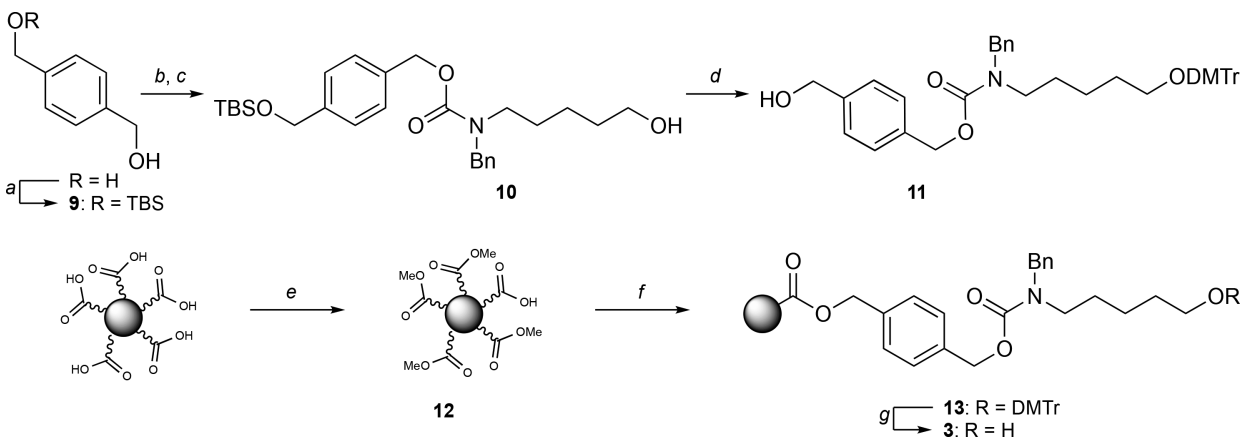

${ }^{a}$ Reagents and conditions: (a) TBDMS-Cl, imidazole, DMF, $0{ }^{\circ} \mathrm{C}(30 \%)$; (b) para-nitrophenylchloroformate, pyridine, $0{ }^{\circ} \mathrm{C}$; (c) $\mathrm{N}$-benzyl-5aminopentanol, DIPEA, DMF, $0{ }^{\circ} \mathrm{C}$ (90\%); (d) (i) DMTr-Cl, pyridine, $0{ }^{\circ} \mathrm{C}$; (ii) TBAF, THF, $0{ }^{\circ} \mathrm{C}(100 \%)$; (e) $\mathrm{TMSCHN}_{2}$, MeOH, THF; (f) 11 , DIC, DMAP, DCM, then MeOH; (g) TCA, DCM.

to drive reactions to completion. The introduction of new protecting groups and protecting group chemistry will be crucial for the further development of automated solid-phase oligosaccharide synthesis.

We introduced the cyanopivaloyl (PivCN) group as an attractive participating group that allows for the reliable construction of 1,2-trans-glycosidic linkages. ${ }^{12}$ It features the favorable characteristics of the pivaloyl ester-stability, effective neighboring group participation, minimal othoester formation, and migratory aptitude-while it circumvents the drawbacks of the parent pivaloyl group-its problematic removal at the end of the synthesis-as it can be removed by reduction of the cyano group to the corresponding amine, which can engage in an effective intramolecular ring closure to cleave the ester function. Thus, removal of the cyanopivaloyl group can be effected in tandem with the removal of benzyl ethers, commonly used as permanent protecting groups.

These favorable characteristics should make the cyanopivaloyl group an attractive protecting group to be used in automated synthesis. To probe its effectiveness in an automated solid-phase setting, we explored its use in the assembly of a set of oligorhamnosides, up to 16 monosaccharides in length (see Figure 1). These target structures represent fragments of the backbone of the cell wall polysaccharide of group A Streptococcus (GAS), a Gram-positive bacterium, which is the cause of various infections (pharyngitidis, necrotizing fasciitis) and which is found responsible for rheumatic fever, causing hundreds of thousands of deaths every year in developing countries. $^{13,14}$ The GAS polyrhamnose backbone is decorated with $\mathrm{N}$-acetyl glucosamine appendages at the rhamnosyl C-3 hydroxyl. ${ }^{15}$ The potential use of this naturally occurring polysaccharide in conjugate vaccines may be thwarted by the potentially autoimmunogenic GlcNAc epitopes, and it has been suggested that the nonmammalian "bare" polyrhamnose backbone, devoid of GlcNAc groups, may be an attractive structure for a GAS vaccine. Well-defined fragments of the polyrhamnose backbone will be valuable in the generation of semisynthetic vaccines and therefore represent attractive synthetic targets. ${ }^{16-22}$ The repetitive nature of these molecules makes them very well suited for an automated synthesis approach.

\section{RESULTS AND DISCUSSION}

The synthetic strategy and test case for the cyanopivaloyl group for the assembly of the oligorhamnosides are depicted in Scheme 1. In this study, a commerical Glyconeer 2.1 synthesizer was used for the automated assembly. The oligosaccharides are built on a polystyrene resin equipped with a linker system ${ }^{23}$ that provides the target structures with an aminopentanol spacer after global deprotection. The amine in the linker system is protected with a benzyl and a modified $\mathrm{Cbz}$ protecting group. The $\mathrm{Cbz}$ part is connected to the solid support via a base-labile ester linkage. Disaccharide building blocks were used in this study bearing an imidate as anomeric leaving group and a levulinoyl group as orthogonal temporary group, as these functionalities have proven very effective in various previous automated solid-phase assembly proce- 
Scheme 2. Synthesis of Donors 1 and $2^{a}$

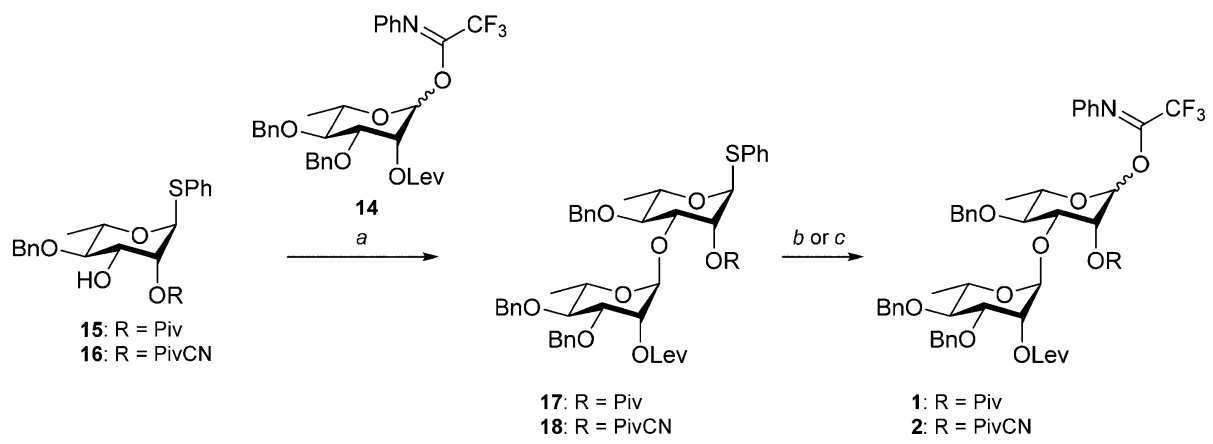

${ }^{a}$ Reagents and conditions: (a) 14, TfOH, DCM, $0{ }^{\circ} \mathrm{C}(17,69 \%, 18,88 \%)$; (b) NBS, acetone $/ \mathrm{H}_{2} \mathrm{O}(19,65 \%, 20,89 \%)$, then $\mathrm{ClC}(=\mathrm{NPh}) \mathrm{CF}_{3}$, $\mathrm{Cs}_{2} \mathrm{CO}_{3}$, acetone, $0{ }^{\circ} \mathrm{C}(1,88 \%, 2,79 \%)$; (c) NIS, TFA, DCM, $0{ }^{\circ} \mathrm{C}(\mathbf{2 0 a}, 73 \%)$, then $\mathrm{ClC}(=\mathrm{NPh}) \mathrm{CF}_{3}, \mathrm{Cs}_{2} \mathrm{CO}_{3}$, acetone, $0{ }^{\circ} \mathrm{C}(\mathbf{2}, 79 \%)$.

Scheme 3. Automated Synthesis of Decamers 21 and 22 and Hexadecamer $23^{a}$

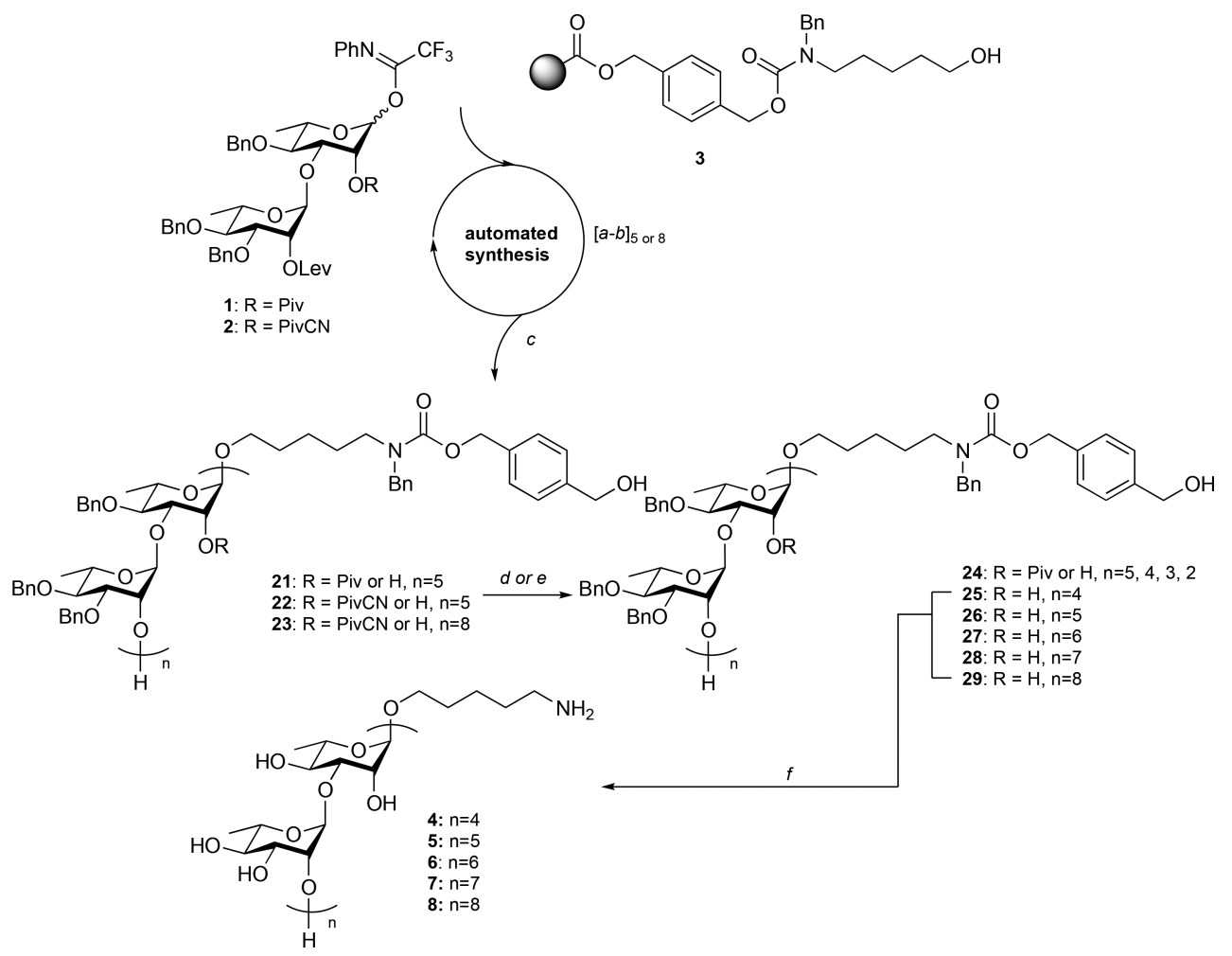

${ }^{a}$ Reagents and conditions: (a) 3 equiv of 1 or 2 , 0.3 equiv of TfOH, DCM, $0{ }^{\circ} \mathrm{C}, 3$ cycles; (b) 8 equiv of $\mathrm{H}_{2} \mathrm{NNH}_{2} \cdot \mathrm{AcOH}, \mathrm{pyr} / \mathrm{AcOH}, 40{ }^{\circ} \mathrm{C}, 3$ cycles; (c) NaOMe, MeOH/THF; (d) NaOMe, MeOH/THF (25, 9\%, 26, 26\%, 27, 6\%, 28, 9\%, 29, 9\% starting from resin 3); (e) $\mathrm{NaOH}$ (aq), $\mathrm{MeOH} /$ dioxane, $40{ }^{\circ} \mathrm{C}$; (f) $\mathrm{H}_{2}, \mathrm{Pd}\left(\mathrm{OH}_{2}\right) / \mathrm{C}, \mathrm{AcOH}, \mathrm{H}_{2} \mathrm{O} / \mathrm{THF} / \mathrm{BuOH}(4,69 \%, 5,57 \%, 6,27 \%, 7,92 \%, 8,50 \%)$.

dures. ${ }^{6,11}$ Dimer donors were to be used because acyl groups at the axial C-2 hydroxyl of rhamnosides are prone to migrate to the equatorial C-3 hydroxyl group when this functionality is unmasked during the synthesis. Partial migration of protecting groups will lead to complex and inseparable mixtures after several coupling rounds. Two different dimer building blocks were explored: the first (dimer 1) carrying a permanent pivaloyl ester at the C-2 hydroxyl and the second (building block 2) with a cyanopivaloyl at this position.

The linker-functionalized resin 3 is obtained in seven steps from 1,4-benzenedimethanol, following an improved route of synthesis, originally developed by Czechura et al., as depicted in Scheme $1{ }^{23}$ After silylation of one hydroxyl group (30\% yield), the remaining hydroxyl is transformed into an active carbonate by reaction of compound 9 with para-nitrophenylchlorofor- mate and reacted with $N$-benzyl-5-aminopentanol to yield compound 10. Installation of the dimethoxytrityl group proceeded uneventfully, but because purification of the fully protected linked system from excess reagent proved troublesome, the TBS group was directly removed. Compound 11 was obtained pure in quantitative yield over two steps on $16 \mathrm{mmol}$ scale.

Next, the linker was conjugated to the carboxylic-acidfunctionalized polystyrene resin. Because the loading of the commercially available resin was too high $(2.19 \mathrm{mmol} / \mathrm{g})$, the amount of carboxylic acid groups was first reduced by treatment of the resin with TMS-diazomethane. ${ }^{24,25}$ Afterward, the resulting resin was coupled with the DMT-protected linker. Removal of the DMTr group was achieved by a TCA/DCM 


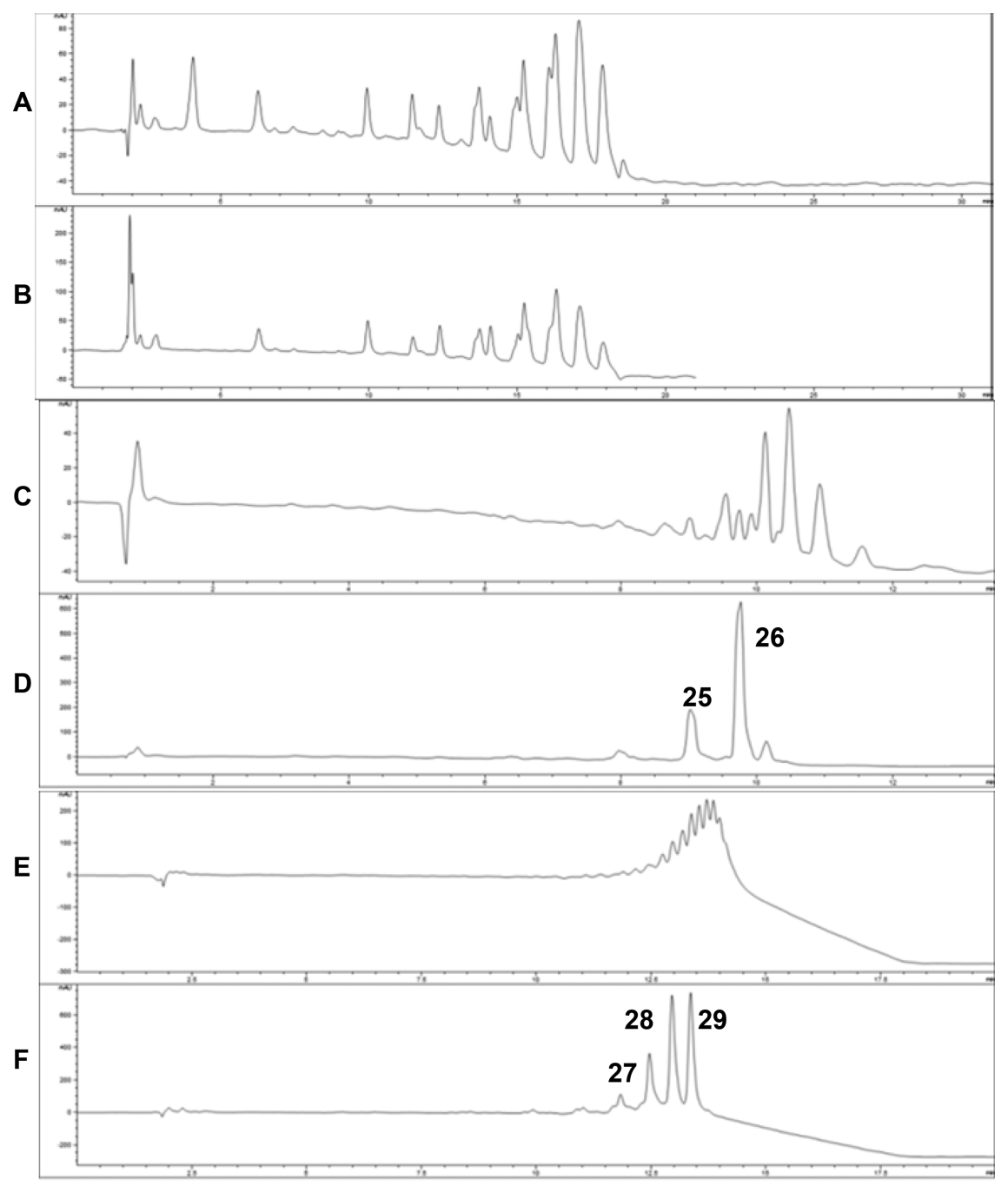

Figure 2. LC chromatogram of the crude products cleaved from the resin before and after prolonged base treatment: (A) 21; (B) 24; (C) 22; (D) 26; (E) 23; (F) 29. Reagents and conditions: (A) diphenyl column, $50 \rightarrow 90 \%$ B; (B) diphenyl column, $50 \rightarrow 90 \%$ B; (C) C4 column, $50 \rightarrow 90 \%$ B; (D) C4 column, $50 \rightarrow 90 \%$ B; (E) diphenyl column, $50 \rightarrow 98 \%$ B; (F) diphenyl column, $50 \rightarrow 98 \%$ B.

treatment, after which the loading was determined to be $0.44-$ $0.47 \mathrm{mmol} / \mathrm{g}$.

The synthesis of the required dirhamnosyl building blocks is depicted in Scheme 2 and started by coupling imidate donor $14^{12}$ and acceptor $15^{26} / 16^{12}$ using a catalytic amount of TfOH. This led to disaccharides $\mathbf{1 7}$ and $\mathbf{1 8}$, which could both be purified by crystallization from hot ethanol. The thioglycosides $17 / 18$ were transformed into the corresponding imidate donors by treatment with $\mathrm{N}$-bromosuccinimide in acetone/water ${ }^{21}$ and subsequent installation of the $\mathrm{N}$-phenyl trifluoroacetimidoyl functionality. ${ }^{27}$

With the required building blocks in hand, the assembly of the oligosaccharides was started. As a first research objective, the assembly of a decasaccharide was targeted, employing the pivaloyl-protected building block 1. Previously developed glycosylation and deprotection conditions ${ }^{6,11}$ were applied to couple donor 1 to resin 3 ( $3 \times 3$ equiv of donor, 0.2 equiv of $\mathrm{TfOH}$ with respect to the donor, $30 \mathrm{~min}$ at $0{ }^{\circ} \mathrm{C}$, Scheme 3 ), followed by removal of the Lev group $(3 \times 5$ equiv of $\mathrm{H}_{2} \mathrm{NNH}_{2} \cdot \mathrm{AcOH}, 10 \mathrm{~min}$ at $40{ }^{\circ} \mathrm{C}$ ). After five coupling/ deprotection cycles, the resin was subjected to cleavage conditions (a catalytic amount of $\mathrm{NaOMe}$ in a mixture of $\mathrm{THF} / \mathrm{MeOH})$.
The crude decasaccharide $\mathbf{2 1}$ was analyzed by LC-MS, and the obtained LC-spectrum is shown in Figure 2. A complex mixture was obtained, which was the result of incomplete glycosylation reactions and removal of some of the pivaloyl esters. Unfortunately, it proved to be impossible to remove all pivaloyl esters, even under harsh basic conditions $(\mathrm{NaOH}$ in $\mathrm{MeOH} /$ dioxane at elevated temperature (conditions e, Scheme $3)^{28}$ and the desired decasaccharide could not be obtained from the complex reaction mixture (Figure 2B). The use of pivaloyl-funtionalized donor 1 was therefore not further explored, and attention was switched to the use of its PivCN counterpart 2.

When donor 2 was used for the assembly of decasaccharide 22, again a complex product mixture arose after cleavage of the products from the resin (Figure 2C). ${ }^{29}$ It was noted, however, that a significantly larger portion of the PivCN groups had been removed from the target structures in comparison to the pivaloyl decasaccharide mixture. This indicates that the cyano group in the PivCN ester renders the ester carbonyl more electrophilic, as a result of its electron-withdrawing character, even though it is separated from the carbonyl by two carbon atoms. ${ }^{30}$ This also suggested that the PivCN groups could potentially be removed by an additional and/or elongated base 
treatment. To explore this possibility, the crude mixture was resubjected to basic conditions, and progress of the reaction was monitored by LC-MS. The LC chromatogram of the mixture that was finally obtained is shown in Figure 2D, and it shows the presence of only two products. The major product in the mixture proved to be the desired decasaccharide 26, whereas the other minor peak corresponds to the octasaccharide (25). Purification of the target compound was readily achieved from this mixture, and the target decasaccharide was obtained in $26 \%$ overall yield after 12 steps ( $89 \%$ per step).

Driven by this success, a hexadecasaccharide was synthesized by running eight coupling/deprotection cycles using donor 2 . After cleavage of the products from the resin, a complex mixture was obtained (Figure 2E). Subjection of this mixture to an additional base treatment led to complete cleavage of all PivCN groups, and Figure 2F depicts the LC chromatogram of the resulting mixture. From this mixture, the target hexadecarhamnoside 29 was obtained in $9 \%$ yield (18 steps, $87 \%$ per step) alongside the dodeca- and tetradecasaccharide deletion sequences, 27 and $\mathbf{2 8}$, respectively.

To complete the syntheses of the oligorhamnosides, all obtained partially protected oligorhamnosides (25-29) were subjected to hydrogenolysis over $\mathrm{Pd}(\mathrm{OH})_{2} / \mathrm{C}$ in $\mathrm{H}_{2} \mathrm{O} / \mathrm{THF} /$ $t \mathrm{BuOH}$ to remove all benzyl groups and liberate the alcohols and the amine functionality on the spacer. Gel filtration (HW40, eluted with $\mathrm{NH}_{4} \mathrm{OAc}$ ) yielded the fully deprotected octa-, deca-, dodeca-, tetradeca-, and hexadecasaccharides (48) in multimilligram quantities.

\section{CONCLUSION}

We have introduced the cyanopivaloyl (PivCN) ester as an effective protecting group for solid-phase oligosaccharide synthesis. This novel protecting group was probed in the assembly of a series of oligorhamnosides, alongside its pivaloyl counterpart. It was found that cleavage of the protected oligosaccharides from the resin was accompanied by partial cleavage of the pivaloyl groups. Complete removal of all pivaloyl groups, however, proved to be difficult, underscoring the problems often encountered with this bulky ester. The cyanopivaloyl ester on the other hand could be effectively cleaved under basic conditions, as a result of the remote electron-withdrawing cyano group, which renders the ester carbonyl group more electrophilic. The favorable cleavage characteristics of the PivCN group in combination with the favorable properties of the pivaloyl-type esters (minimal orthoester formation during glycosylations, minimal migration, stability) make the PivCN group an attractive asset in the toolbox of the synthetic chemist. Here, it has proven its merits in the automated solid-phase assembly of GAS-related oligorhamnosides of considerable length.

\section{EXPERIMENTAL SECTION}

General Experimental Procedures. All solvents used under anhydrous conditions were stored over $4 \AA$ molecular sieves except for methanol, which was stored over $3 \AA$ molecular sieves. ${ }^{1} \mathrm{H}$ and ${ }^{13} \mathrm{C}$ NMR spectra were recorded on a $400 / 100,500 / 125,600 / 150$, or a $850 / 214 \mathrm{MHz}$ spectrometer. Chemical shifts $(\delta)$ are given in parts per million relative to tetramethylsilane as internal standard. Coupling constants are given in hertz. All individual signals were assigned using 2D NMR spectroscopy, $\mathrm{HH}-\mathrm{COSY}, \mathrm{HSQC}$, and HMBC. IR spectra are reported in $\mathrm{cm}^{-1}$ and recorded on a Shimadzu FTIR-8300 or a PerkinElmer universal attenuated total reflectance (UATR; single reflection diamond) Spectrum Two instrument. Solvents used for workup and column chromatography were of technical grade from
Sigma-Aldrich, Boom, Biosolve, or Honeywell and used directly. Unless stated otherwise, solvents were removed by rotary evaporation under reduced pressure at $40{ }^{\circ} \mathrm{C}$. All chemicals were used as received unless stated otherwise. Reactions were monitored by TLC analysis using Merck 25 DC plastikfolien 60 F254 with detection by spraying with $20 \% \mathrm{H}_{2} \mathrm{SO}_{4}$ in EtOH, $\left(\mathrm{NH}_{4}\right)_{6} \mathrm{Mo}_{7} \mathrm{O}_{24} \cdot 4 \mathrm{H}_{2} \mathrm{O}(25 \mathrm{~g} / \mathrm{L})$, and $\left(\mathrm{NH}_{4}\right)_{4} \mathrm{Ce}\left(\mathrm{SO}_{4}\right)_{4} \cdot 2 \mathrm{H}_{2} \mathrm{O}(10 \mathrm{~g} / \mathrm{L})$ in $10 \%$ sulfuric acid, by spraying with a solution of ninhydrin $(3 \mathrm{~g} / \mathrm{L})$ in $\mathrm{EtOH} / \mathrm{AcOH}(20 / 1 \mathrm{v} / \mathrm{v})$, or by dipping in anisaldehyde $\left(10 \mathrm{~mL}\right.$ in $\left.180 \mathrm{~mL} \mathrm{EtOH} / 10 \mathrm{~mL} \mathrm{H}_{2} \mathrm{SO}_{4}\right)$ followed by charring at approximately $150{ }^{\circ} \mathrm{C}$. Column chromatography was performed on Fluka silica gel $(0.04-0.063 \mathrm{~mm})$. For LCMS analysis, an Agilent Technologies 1260 Infinity LC system (detection simultaneously at 214 and $254 \mathrm{~nm}$ ) coupled to a Agilent Technologies 6120 Quadrupole LC/MS, using an analytical Vydac C4 column (Alltech, $50 \times 4.60 \mathrm{~mm}, 5 \mu \mathrm{m}$ ) or a Vydac Diphenyl (Alltech, $150 \times 4.60 \mathrm{~mm}, 5 \mu \mathrm{m})$ in combination eluents $\mathrm{A}\left(\mathrm{H}_{2} \mathrm{O}\right),(\mathrm{B}) \mathrm{MeCN}$, and (C) $1 \%$ aqueous TFA. For HPLC, a Gilson HPLC system in combination with eluents $\mathrm{A}\left(\mathrm{H}_{2} \mathrm{O}, 0.1 \%\right.$ TFA $)$ and $\mathrm{B}(\mathrm{MeCN}$ as the solvent system using a Vydac C4 HPLC column; Grace, $250 \times 10 \mathrm{~mm}$, $5 \mu \mathrm{m})$. High-resolution mass spectra were recorded by direct injection ( $2 \mu \mathrm{L}$ of a $2 \mu \mathrm{M}$ solution in water/acetonitrile; 50/50; v/v and $0.1 \%$ formic acid) on a mass spectrometer (Thermo Finnigan LTQ Orbitrap) equipped with an electrospray ion source in positive mode (source voltage $3.5 \mathrm{kV}$, sheath gas flow 10 , capillary temperature $250{ }^{\circ} \mathrm{C}$ ) with resolution $R=60000$ at $\mathrm{m} / z 400$ (mass range $\mathrm{m} / z=$ $150-2000)$ and dioctyl phthalate $(m / z=391.2842)$ as a "lock mass". The high-resolution mass spectrometer was calibrated prior to measurements with a calibration mixture (Thermo Finnigan). MALDI spectra were recorded on an Ultraflextreme MALDI-TOF (Bruker Daltonics), equipped with Smartbeam-II laser, to measure the samples in reflectron positive ion mode. The MALDI-TOF was calibrated using a peptide calibration standard prior to measurement. One microliter of 2,5-dihydroxybenzoic acid (Bruker Daltonics) matrix $(20 \mathrm{mg} / \mathrm{mL}$ in ACN/water; 50:50 (v/v)) was applied on a 384-MTP target plate (Bruker Daltonics, Bremen, Germany) and air-dried. Subsequently, $1 \mu \mathrm{L}$ of compound water solution was spotted on the plate, and the spots were left to dry prior to MALDI-TOF analysis.

(4-tert-Butyldimethylsiloxylmethylphenyl)methanol (9). 1,4Benzenedimethanol ( $8.29 \mathrm{~g}, 60 \mathrm{mmol}, 1.0$ equiv) was dissolved in 25 $\mathrm{mL}$ of $\mathrm{DMF}$ and cooled to $0{ }^{\circ} \mathrm{C}$ followed by the addition of imidazole (10.2 g, $150 \mathrm{mmol}, 2.5$ equiv). A solution of tert-butyldimethylsilyl chloride ( $9.13 \mathrm{~g}, 60.6 \mathrm{mmol}, 1.01$ equiv) in $40 \mathrm{~mL}$ of DMF was added dropwise, and the reaction was allowed to stir overnight. After TLC analysis showed complete consumption of the starting material, the mixture was diluted with $\mathrm{Et}_{2} \mathrm{O}$ and washed subsequently with $\mathrm{H}_{2} \mathrm{O}$ $(2 \times)$ and saturated aqueous $\mathrm{NaCl}(1 \times)$. The organic phase was dried over $\mathrm{MgSO}_{4}$ and concentrated in vacuo. Purification using flash column chromatography (PE/EtOAc, 9:1 $\rightarrow$ 6:1) yielded the title compound as a colorless oil $(4.73 \mathrm{~g}, 18.7 \mathrm{mmol}, 30 \%): R_{f} 0.39$ (PE/ EtOAc, 6/1, v/v); ${ }^{1} \mathrm{H}$ NMR (400 MHz, $\left.\mathrm{CDCl}_{3}\right) \delta 7.33(\mathrm{~s}, 4 \mathrm{H}), 4.74$ $(\mathrm{s}, 2 \mathrm{H}), 4.68(\mathrm{~d}, 2 \mathrm{H}, J=3.1 \mathrm{~Hz}), 1.67-1.50(\mathrm{~m}, 2 \mathrm{H}), 0.94(\mathrm{~s}, 9 \mathrm{H})$, $0.10(\mathrm{~s}, 6 \mathrm{H})$. Analytical data are identical to literature values. ${ }^{31}$

$N$-Benzyl-5-aminopentanol. Benzaldehyde (10.67 mL, 104.6 mmol, 1.01 equiv) was added to a solution of 5 -aminopentalnol (11.3 $\mathrm{mL}, 104.0 \mathrm{mmol}, 1.0$ equiv) in $150 \mathrm{~mL}$ of EtOH. The solution was heated to $50{ }^{\circ} \mathrm{C}$ under reduced pressure until all solvent was removed. The crude mixture was coevaporated twice with anhydrous toluene, dissolved in $\mathrm{MeOH}(200 \mathrm{~mL})$, and cooled to $0{ }^{\circ} \mathrm{C}$. $\mathrm{NaBH}_{4}(4.82 \mathrm{~g}$, $124.7 \mathrm{mmol}, 1.2$ equiv) was added in portions, and the solution was allowed to stir at $0{ }^{\circ} \mathrm{C}$ for $70 \mathrm{~min}$. After being stirred for another $2 \mathrm{~h}$, the solution was cooled to $0{ }^{\circ} \mathrm{C}$ followed by addition of $4.5 \mathrm{~mL}$ of AcOH. A $1.2 \mathrm{M} \mathrm{K}_{2} \mathrm{CO}_{3}$ (aq) solution $(135 \mathrm{~mL}$ ) was added, and the mixture was diluted with $\mathrm{Et}_{2} \mathrm{O}$. The organic layer was dried over $\mathrm{MgSO}_{4}$ and concentrated in vacuo. Purification using flash column chromatography yielded the linker in $62 \%$ yield $(12.4 \mathrm{~g}, 64 \mathrm{mmol}):{ }^{1} \mathrm{H}$ NMR (400 MHz, $\left.\mathrm{CDCl}_{3}\right) \delta 7.41-7.15(\mathrm{~m}, 5 \mathrm{H}), 3.78(\mathrm{~s}, 2 \mathrm{H}), 3.62(\mathrm{t}$, $2 \mathrm{H}, J=6.4,6.4 \mathrm{~Hz}), 2.64(\mathrm{t}, 2 \mathrm{H}, J=7.0,7.0 \mathrm{~Hz}), 1.92(\mathrm{~s}, 2 \mathrm{H}), 1.72-$ $1.47(\mathrm{~m}, 4 \mathrm{H}), 1.47-1.25(\mathrm{~m}, 2 \mathrm{H}) ;{ }^{13} \mathrm{C}$ NMR $\left(101 \mathrm{MHz}, \mathrm{CDCl}_{3}\right) \delta$ $140.2,128.5,128.3,127.1,62.7,54.1,49.3,42.0,32.6,29.7,29.1,23.5$. Analytical data are identical to literature values. ${ }^{32}$ 
5-(Benzyl(4-tert-butyldimethylsilyl)oxymethylbenzyloxycarbonyl)amino)pentanol (10). Silylether $9(4.73 \mathrm{~g}, 18.7 \mathrm{mmol}, 1.0$ equiv) was dissolved in dry DCM $(125 \mathrm{~mL})$ and cooled to $0{ }^{\circ} \mathrm{C}$. Pyridine (3.0 mL, $37.5 \mathrm{mmol}, 2.0$ equiv) was added followed by addition of para-nitrophenylchloroformate $(4.53 \mathrm{~g}, 22.5 \mathrm{mmol}, 1.2$ equiv), after which the solution was allowed to warm to RT and stirred overnight. The reaction was concentrated in vacuo and coevaporated with toluene. The crude compound was dissolved in DMF $(75 \mathrm{~mL})$ and cooled to $0{ }^{\circ} \mathrm{C}$. To this mixture was added $\mathrm{N}$-benzyl-5aminopentanol (4.78 g, $23.0 \mathrm{mmol}, 1.23$ equiv) in DMF $(20 \mathrm{~mL})$ followed by addition of DIPEA ( $4.23 \mathrm{~mL}, 24.4 \mathrm{mmol}, 1.3$ equiv) The reaction mixture was stirred overnight, diluted with $\mathrm{Et}_{2} \mathrm{O}$, and washed with $\mathrm{H}_{2} \mathrm{O}$. The aqueous layer was back extracted with $\mathrm{Et}_{2} \mathrm{O}$, and the combined organic layers were washed multiple times with saturated aqueous $\mathrm{NaHCO}_{3}$. The solution was dried over $\mathrm{MgSO}_{4}$, filtered, and concentrated in vacuo. Column purification (PE/EtOAc, 8:1 $\rightarrow$ 3:1) yielded the title compound $(8.02 \mathrm{~g}, 17.0 \mathrm{mmol}, 90 \%)$ : IR (neat) 1083, 1249, 1417, 1454, 1681, 1695, 2856, 2929, 2949, 3062, 3387, 3437 $\mathrm{cm}^{-1}$; ${ }^{1} \mathrm{H}$ NMR $\left(500 \mathrm{MHz}, \mathrm{CDCl}_{3}\right) \delta 7.21-7.10\left(\mathrm{~m}, 9 \mathrm{H}, \mathrm{CH}_{\text {arom }}\right)$, 5.06 (s, $2 \mathrm{H}, \mathrm{CH}_{2} \mathrm{Cbz}$ ), 4.63 (s, $\left.2 \mathrm{H}, \mathrm{CH}_{2} \mathrm{Bn}\right), 4.39$ (s, $2 \mathrm{H}, \mathrm{CH}_{2} \mathrm{Cbz}$ ), $3.46\left(\mathrm{~s}, 2 \mathrm{H}, \mathrm{CH}_{2}\right), 3.15\left(\mathrm{~s}, 2 \mathrm{H}, \mathrm{CH}_{2}\right), 1.41-1.20\left(\mathrm{~s}, 6 \mathrm{H}, 3 \times \mathrm{CH}_{2}\right)$, 0.85 (s, 9H, $3 \times \mathrm{CH}_{3}$ TBDMS), $0.00\left(\mathrm{~s}, 6 \mathrm{H}, 2 \times \mathrm{CH}_{3}\right.$ TBDMS $) ;{ }^{13} \mathrm{C}$ NMR $\left(126 \mathrm{MHz}, \mathrm{CDCl}_{3}\right) \delta 141.5,138.3,135.7$ (Cq), 128.7, 128.1, 127.5, $126.4\left(\mathrm{CH}_{\text {arom }}\right), 67.3\left(\mathrm{CH}_{2}\right), 65.0\left(\mathrm{CH}_{2}\right), 62.9\left(\mathrm{CH}_{2}\right), 50.7$ $\left(\mathrm{CH}_{2}\right), 32.6\left(\mathrm{CH}_{2}\right), 26.1\left(3 \times \mathrm{CH}_{3}\right.$ TDBDMS $), 23.2\left(\mathrm{CH}_{2}\right),-5.1(2$ $\times \mathrm{CH}_{3}$ TBDMS); HRMS $[\mathrm{M}+\mathrm{H}]^{+}$calcd for $\mathrm{C}_{27} \mathrm{H}_{42} \mathrm{NO}_{4} \mathrm{Si} 472.2878$, found 472.2877 .

5-(Benzyl(4-hydroxymethylbenzyloxycarbonyl)amino)pentyldimethoxytrityl ether (11). Silylether $10(7.50 \mathrm{~g}, 15.9 \mathrm{mmol}$, 1.0 equiv) was coevaporated twice with pyridine under an argon atmosphere, before being dissolved in pyridine $(160 \mathrm{~mL})$ and cooled to $0{ }^{\circ} \mathrm{C}$. To the mixture was added DMTr-Cl $(5.92 \mathrm{~g}, 17.5 \mathrm{mmol}, 1.1$ equiv), and it was allowed to stir overnight. After being stirred overnight, TLC analysis (hexanes/EtOAc, 4:1) showed conversion of the starting material to a high running spot. The mixture was concentrated, dissolved in EtOAc and washed twice with $\mathrm{H}_{2} \mathrm{O}$, dried over $\mathrm{MgSO}_{4}$, and concentrated in vacuo. The intermediate was coevaporated with toluene, dissolved in THF $(160 \mathrm{~mL})$, and cooled to $0{ }^{\circ} \mathrm{C}$. TBAF (1.0 M in THF, $25 \mathrm{~mL}, 1.6$ equiv) was added, and the green colored reaction was stirred for $5 \mathrm{~h}$, after which it was concentrated. The compound was dissolved in EtOAc, washed subsequently with $\mathrm{H}_{2} \mathrm{O}$, saturated aqueous $\mathrm{NaHCO}_{3}$, and saturated aqueous $\mathrm{NaCl}$. The organic layer was dried over $\mathrm{MgSO}_{4}$ and concentrated in vacuo. Purification by column chromatography $\left(\mathrm{Tol} / \mathrm{EtOAc}+\mathrm{Et}_{3} \mathrm{~N}, 9: 1 \rightarrow 4: 1\right)$ yielded DMTr-protected linker (10.2 g, 15.9 mmol, 100\%): IR (neat) 1031, 1246, 1300, 1417, 1506, 1606, 1693, 2835, 2864, 2931, 3030, 3059, 3415, $3441 \mathrm{~cm}^{-1}$; ${ }^{1} \mathrm{H}$ NMR $\left(400 \mathrm{MHz}, \mathrm{CDCl}_{3}, T=328 \mathrm{~K}\right) \delta 7.41\left(\mathrm{~d}, J=7.6 \mathrm{~Hz}, 2 \mathrm{H}, \mathrm{CH}_{\text {arom }}\right)$, 7.35-7.07 (m, $\left.16 \mathrm{H}, \mathrm{CH}_{\text {arom }}\right), 6.80\left(\mathrm{~d}, J=8.5 \mathrm{~Hz}, 4 \mathrm{H}, \mathrm{CH}_{\text {arom }}\right), 5.13$ (s, $\left.2 \mathrm{H}, \mathrm{CH}_{2} \mathrm{Cbz}\right), 4.63$ (s, 2H, $\left.\mathrm{CH}_{2} \mathrm{Bn}\right), 4.46\left(\mathrm{~s}, 2 \mathrm{H}, \mathrm{CH}_{2} \mathrm{Cbz}\right), 3.76$ $\left(\mathrm{s}, 6 \mathrm{H}, 2 \times \mathrm{CH}_{3} \mathrm{OMe}\right), 3.21\left(\mathrm{~s}, 2 \mathrm{H}, \mathrm{CH}_{2}\right), 3.02\left(\mathrm{~s}, 2 \mathrm{H}, \mathrm{CH}_{2}\right), 1.69-$ $1.24\left(\mathrm{~m}, 6 \mathrm{H}, 3 \times \mathrm{CH}_{2}\right) ;{ }^{13} \mathrm{C} \mathrm{NMR}\left(101 \mathrm{MHz}, \mathrm{CDCl}_{3}\right) \delta 158.6,145.6$, $140.9,136.9$ (Cq), 130.2, 128.6, 128.4, 128.2, 127.8, 127.4, 127.1, 126.7, $113.2\left(\mathrm{CH}_{\text {arom }}\right), 67.1\left(\mathrm{CH}_{2}\right), 65.1\left(\mathrm{CH}_{2}\right), 63.4\left(\mathrm{CH}_{2}\right), 55.3$ (OMe), $29.9\left(\mathrm{CH}_{2}\right), 23.8\left(\mathrm{CH}_{2}\right)$; HRMS $[\mathrm{M}+\mathrm{Na}]^{+}$calcd for $\mathrm{C}_{42} \mathrm{H}_{45} \mathrm{NO}_{6} \mathrm{Na}$ 682.3139, found 682.3139. (12).

Synthesis of Aminopentanol-Functionalized Polystyrene

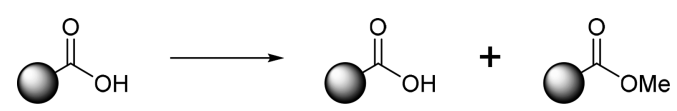

Carboxy polystyrene (Rapp polymer, $5 \mathrm{~g}, 2.19 \mathrm{mmol} / \mathrm{g}, 11 \mathrm{mmol}$ ) was added to a fritted syringe and swollen in $32 \mathrm{~mL}$ of DCM. The resin was purged with argon, after which it was washed with DCM $(3 \times)$, alternating DCM and hexane $(3 \times)$, and DCM $(2 \times)$. The resin was dried in vacuo at $45{ }^{\circ} \mathrm{C}$ overnight. The dried resin was suspended in $60 \mathrm{~mL}$ of THF, and $\mathrm{MeOH}(1.03 \mathrm{~mL}, 25.4 \mathrm{mmol}, 3$ equiv with respect to $\mathrm{Me}_{3} \mathrm{SiCHN}_{2}$ ) was added. The suspension was shaken for $10 \mathrm{~min}$ followed by addition of $\mathrm{Me}_{3} \mathrm{SiCHN}_{2}$ (4.24 mL of $2.0 \mathrm{M}$ solution in hexanes, $8.47 \mathrm{mmol}, 0.77$ equiv with respect to the resin), whereupon the solution turned yellow. The reaction was allowed to shake overnight, after which it became colorless. The solution was filtered, and resin 12 was washed with DCM (4X), hexanes (4X), and THF $(4 \times)$ and dried in vacuo at $45{ }^{\circ} \mathrm{C}$.

Carboxy polystyrene 12 (Rapp polymer, $5 \mathrm{~g}, \sim 0.51 \mathrm{mmol} / \mathrm{g}, 2.54$ $\mathrm{mmol})$ was swollen in DCM $(60 \mathrm{~mL})$, and the suspension was shaken for $1 \mathrm{~h}$. The solution was filtered, and DCM $(40 \mathrm{~mL})$ was added to the resin. Compound 11 (5.04 g, $7.64 \mathrm{mmol}, 3$ equiv) was coevaporated twice with toluene under argon, dissolved in DCM $(8.5 \mathrm{~mL})$, with addition of DIC $(1.20 \mathrm{~mL}, 7.64 \mathrm{mmol}, 3$ equiv) and DMAP $(0.03 \mathrm{~g}$, $0.25 \mathrm{mmol}, 0.1$ equiv). An additional rinse with $5 \mathrm{~mL}$ of DCM was performed before the resin was allowed to shake overnight. Then, $\mathrm{MeOH}(0.6 \mathrm{~mL})$ was added, and the suspension was shaken again. The mixture was filtered, and resin $\mathbf{1 3}$ was washed with alternating DCM and hexanes $(4 \times)$, followed by DCM $(3 \times)$. The resin was dried in vacuo at $45{ }^{\circ} \mathrm{C}$.

Solid Support (3). DMT-functionalized resin $13(5 \mathrm{~g})$ was loaded into a fritted funnel and washed with $3 \%$ TCA (w/v in DCM, $60 \mathrm{~mL}$ ) and shaken for $5 \mathrm{~min}$. The orange solution was filtered, and the procedure was repeated $4 \times$. After the TCA washes, the orange resin was washed $3 \times$ with DCM $(60 \mathrm{~mL}), 3 \times$ with toluene $(60 \mathrm{~mL}), 3 \times$ with $\mathrm{DCM} / \mathrm{MeOH}(60 \mathrm{~mL}), 1 \times$ with $\mathrm{MeOH}(60 \mathrm{~mL})$, and $4 \times \mathrm{DCM}$ $(60 \mathrm{~mL})$. The resin was dried in vacuo to a constant weight of $4.22 \mathrm{~g}$.

DMTr Assay (Performed in Duplicate). DMT-functionalized resin $13(4.1 \mathrm{mg})$ was added to a $10 \mathrm{~mL}$ volumetric flask and treated with $10 \mathrm{~mL}$ of $3 \% \mathrm{TCA} / \mathrm{DCM}(\mathrm{w} / \mathrm{v})$. A $1 \mathrm{~mL}$ aliquot was taken and diluted $100 \times$ with the $3 \% \mathrm{TCA} / \mathrm{DCM}$ solution. Absorbance read at $\lambda$ $=503 \mathrm{~nm}$.

$$
\begin{aligned}
& \text { Loading calculation: } \\
& \frac{\left[\left(A_{503}\right)(100 \mathrm{~mL})\right]}{76}=\mathrm{mmol} \text { in final solution } \\
& \left(\frac{\text { mmol in final solution }}{\text { volume aliquot }}\right) \times 10 \mathrm{~mL}=\mathrm{mmol} \text { in initial solution } \\
& =\frac{(0.137)(100 \mathrm{~mL})}{76 \mathrm{~mL} / \mu \mathrm{mol}}=0.180 \mu \mathrm{mol} \\
& =\left(\frac{0.00018 \mathrm{mmol}}{1 \mathrm{~mL}}\right) \times 10 \mathrm{~mL}=0.00180 \mathrm{mmol} \\
& \text { loading }=\frac{0.00180 \mathrm{mmol}}{0.0041 \mathrm{~g}}=0.44 \mathrm{mmol} / \mathrm{g}
\end{aligned}
$$

A loading of $0.44-0.47 \mathrm{mmol} / \mathrm{g}$ was determined.

Phenyl 4-O-Benzyl-2-O-pivaloyl-3-O-(3,4-di-O-benzyl-2-Olevulinoyl- $\alpha$-L-rhamnopyranosyl)-1-thio- $\alpha$-L-rhamnopyranoside (17). Compound $15^{26}$ (4.96 g, $11.52 \mathrm{mmol}, 1.0$ equiv) and imidate donor 14 ( $7.56 \mathrm{~g}, 13.32 \mathrm{mmol}, 1.2$ equiv) were coevaporated twice with anhydrous toluene under an argon atmosphere, after which they were dissolved in dry DCM $(56 \mathrm{~mL})$. The mixture was stirred on activated molecular sieves for $20 \mathrm{~min}$ at $\mathrm{RT}$ and then cooled to $0{ }^{\circ} \mathrm{C}$. $\mathrm{TfOH}(0.1 \mathrm{~mL}, 1.12 \mathrm{mmol}, 0.1$ equiv) was added, and after $135 \mathrm{~min}$, TLC analysis showed complete consumption of the acceptor, and the reaction was quenched by addition of $0.3 \mathrm{~mL}$ of $\mathrm{Et}_{3} \mathrm{~N}$. The mixture was diluted with EtOAc, washed subsequently with saturated aqueous $\mathrm{NaHCO}_{3}$ and saturated aqueous $\mathrm{NaCl}$, dried over $\mathrm{MgSO}_{4}$, and concentrated in vacuo. Crystallization from hot EtOH (5.65 g, 6.61 $\mathrm{mmol}$ ), followed by a second crystallization of the mother liquid, yielded the disaccharide as white crystals $(6.65 \mathrm{~g}, 7.78 \mathrm{mmol}, 69 \%)$ : $\mathrm{mp} 145{ }^{\circ} \mathrm{C} ; R_{f} 0.69$ (PE/EtOAc, 2/1, v/v); IR (neat) 918, 987, 1026, 1039, 1060, 1082, 1138, 1454, 1479, 1732, 2873, 2910, 2933, 2974 $\mathrm{cm}^{-1}$; ${ }^{1} \mathrm{H}$ NMR (500 MHz, $\left.\mathrm{CDCl}_{3}\right) \delta 7.47-7.41\left(\mathrm{~m}, 2 \mathrm{H}, \mathrm{CH}_{\text {arom }}\right)$, $7.36\left(\mathrm{~d}, J=4.4 \mathrm{~Hz}, 4 \mathrm{H}, \mathrm{CH}_{\text {arom }}\right), 7.37-7.16\left(\mathrm{~m}, 13 \mathrm{H}, \mathrm{CH}_{\text {arom }}\right), 5.39$ $\left(\mathrm{dd}, J=3.3,1.8 \mathrm{~Hz}, 1 \mathrm{H}, \mathrm{H}-2^{\prime}\right), 5.35(\mathrm{~d}, J=1.8 \mathrm{~Hz}, 1 \mathrm{H}, \mathrm{H}-1), 5.29$ (dd, $J=3.2,1.8 \mathrm{~Hz}, 1 \mathrm{H}, \mathrm{H}-2), 5.06\left(\mathrm{~d}, J=1.9 \mathrm{~Hz}, 1 \mathrm{H}, \mathrm{H}-1^{\prime}\right), 4.91(\mathrm{~d}, J=$ $11.5 \mathrm{~Hz}, 1 \mathrm{H}, \mathrm{CHH} \mathrm{Bn}$ ), 4.78 (d, $J=10.8 \mathrm{~Hz}, 1 \mathrm{H}, \mathrm{CHH} \mathrm{Bn}$ ), 4.67$4.54\left(\mathrm{~m}, 3 \mathrm{H}, \mathrm{CHH}, \mathrm{CH}_{2} \mathrm{Bn}\right), 4.46(\mathrm{~d}, J=11.5 \mathrm{~Hz}, 1 \mathrm{H}, \mathrm{CHH} \mathrm{Bn})$, $4.26-4.16(\mathrm{~m}, 1 \mathrm{H}, \mathrm{H}-5), 4.11$ (dd, $J=9.4,3.1 \mathrm{~Hz}, 1 \mathrm{H}, \mathrm{H}-3), 3.81$ (dd, 
$\left.J=9.3,3.4 \mathrm{~Hz}, 1 \mathrm{H}, \mathrm{H}-3^{\prime}\right), 3.73-3.64\left(\mathrm{~m}, 1 \mathrm{H}, \mathrm{H}-5^{\prime}\right), 3.49(\mathrm{t}, J=9.5$ $\mathrm{Hz}, 1 \mathrm{H}, \mathrm{H}-4), 3.41\left(\mathrm{t}, J=9.4 \mathrm{~Hz}, 1 \mathrm{H}, \mathrm{H}-4^{\prime}\right), 2.69-2.65(\mathrm{~m}, 4 \mathrm{H}, 2 \times$ $\mathrm{CH}_{2}$ Lev), $2.13\left(\mathrm{~s}, 3 \mathrm{H}, \mathrm{CH}_{3} \mathrm{Lev}\right), 1.33-1.22\left(\mathrm{~m}, 6 \mathrm{H}, 2 \times \mathrm{CH}_{3}-6\right)$, $1.20\left(\mathrm{~s}, 9 \mathrm{H}, 3 \times \mathrm{CH}_{3} \mathrm{Piv}\right) ;{ }^{13} \mathrm{C}$ NMR $\left(126 \mathrm{MHz}, \mathrm{CDCl}_{3}\right) \delta 206.0$ (C=O Lev), 177.3, 171.8 (C=O Lev, Piv), 138.7, 137.8, 137.7, 133.6 (Cq), 132.1, 129.0, 128.5, 128.4, 128.3, 128.2, 127.9, 127.7, 127.6, 127.5, 127.4 ( $\left.\mathrm{CH}_{\text {arom }}\right), 99.7\left(\mathrm{C}-1^{\prime}\right), 85.6(\mathrm{C}-1), 80.4(\mathrm{C}-4), 79.6$ (C$\left.4^{\prime}\right), 77.7(\mathrm{C}-3), 77.2\left(\mathrm{C}-3^{\prime}\right), 75.5\left(\mathrm{CH}_{2} \mathrm{Bn}\right), 74.8\left(\mathrm{CH}_{2} \mathrm{Bn}\right), 73.6(\mathrm{C}-$ 2), $71.5\left(\mathrm{CH}_{2} \mathrm{Bn}\right), 69.3(\mathrm{C}-5), 69.1\left(\mathrm{C}-2^{\prime}\right), 68.5\left(\mathrm{C}-5^{\prime}\right), 39.0(\mathrm{Cq}$ Piv), $38.0\left(\mathrm{CH}_{2} \mathrm{Lev}\right), 29.8\left(\mathrm{CH}_{3} \mathrm{Lev}\right), 28.1\left(\mathrm{CH}_{2} \mathrm{Lev}\right), 27.1\left(\mathrm{CH}_{3}\right.$ Piv), 17.9 (C-6), 17.8 (C-6'); HRMS $[\mathrm{M}+\mathrm{H}]^{+}$calcd for $\mathrm{C}_{49} \mathrm{H}_{62} \mathrm{NO}_{11} \mathrm{~S} 872.4038$, found 872.4045 .

4-O-Benzyl-2-O-pivaloyl-3-O-(3,4-di-O-benzyl-2-O-levulinoyl- $\alpha$-L-rhamnopyranosyl)- $\alpha / \beta$-L-rhamnopyranoside (19). Compound $17(2.76 \mathrm{~g}, 3.23 \mathrm{mmol}, 1.0$ equiv) was dissolved in acetone/ $\mathrm{H}_{2} \mathrm{O}(3: 1,16 \mathrm{~mL})$ and cooled to $0{ }^{\circ} \mathrm{C}$. NBS $(1.73 \mathrm{~g}, 9.69 \mathrm{mmol}, 3.0$ equiv) was added, and the reaction was stirred overnight. TLC analysis showed conversion of the starting material to a lower running spot and the mixture was quenched with saturated aqueous $\mathrm{Na}_{2} \mathrm{~S}_{2} \mathrm{O}_{3}$. The mixture was diluted with EtOAc, and the organic layer was washed with saturated aqueous $\mathrm{NaHCO}_{3}$, dried over $\mathrm{MgSO}_{4}$, and concentrated in vacuo. Purification by column chromatography (PE/EtOAc, $4: 1 \rightarrow 1: 1)$ yielded the title hemiacetal $(1.60 \mathrm{~g}, 2.10 \mathrm{mmol}, 65 \%)$. Spectroscopic data are reported for the major $(\alpha)$ isomer: $R_{f} 0.26(\mathrm{PE} /$ EtOAc, 2/1, v/v); IR (neat) 1064, 1082, 1134, 1163, 1363, 1708, $1776,2875,2933,2974,3381 \mathrm{~cm}^{-1} ;{ }^{1} \mathrm{H} \operatorname{NMR}\left(500 \mathrm{MHz}, \mathrm{CDCl}_{3}\right) \delta$ 7.39-7.15 (m, $\left.15 \mathrm{H}, \mathrm{CH}_{\text {arom }}\right), 5.36\left(\mathrm{dd}, J=3.1,1.8 \mathrm{~Hz}, 1 \mathrm{H}, \mathrm{H}-2^{\prime}\right)$, 5.05-4.99 (m, 3H, H-1, H-1' $\left.{ }^{\prime}, \mathrm{H}-2\right), 4.90(\mathrm{~d}, J=11.4 \mathrm{~Hz}, 1 \mathrm{H}, \mathrm{CHH}$ $\mathrm{Bn}), 4.74(\mathrm{~d}, J=10.8 \mathrm{~Hz}, 1 \mathrm{H}, \mathrm{CHH} \mathrm{Bn}), 4.66-4.51(\mathrm{~m}, 3 \mathrm{H}, \mathrm{CHH} \mathrm{Bn}$, $\mathrm{CH}_{2} \mathrm{Bn}$ ), $4.43(\mathrm{~d}, J=11.5 \mathrm{~Hz}, 1 \mathrm{H}, \mathrm{CHH} \mathrm{Bn}), 4.16(\mathrm{dd}, J=9.5,3.0$ $\left.\mathrm{Hz}, 1 \mathrm{H}, \mathrm{H}-3^{\prime}\right)$, 3.97-3.87 (m, 1H, H-5), 3.79 (dd, $J=9.3,3.3 \mathrm{~Hz}, 1 \mathrm{H}$, $\mathrm{H}-3), 3.71-3.62\left(\mathrm{~m}, 1 \mathrm{H}, \mathrm{H}-5^{\prime}\right), 3.48(\mathrm{~s}, 1 \mathrm{H}, \mathrm{OH}), 3.38$ (dt, $J=9.4,6.7$ $\left.\mathrm{Hz}, 2 \mathrm{H}, \mathrm{H}-4, \mathrm{H}-4^{\prime}\right), 2.73-2.60$ (m, 4H, $\left.2 \times \mathrm{CH}_{2} \mathrm{Lev}\right), 2.15$ (s, 3H, $\mathrm{CH}_{3}$ Lev $), 1.29-1.17\left(\mathrm{~m}, 15 \mathrm{H}, 2 \times \mathrm{CH}_{3} \mathrm{C}-6, \mathrm{C}-6^{\prime}, 3 \times \mathrm{CH}_{3} \mathrm{Piv}\right) ;{ }^{13} \mathrm{C}$ NMR $\left(126 \mathrm{MHz}, \mathrm{CDCl}_{3}\right) \delta 206.5$ (C=O Lev), 177.7, $171.9(\mathrm{C}=\mathrm{O}$ Lev, Piv), 138.8, 138.8, 137.9, 137.9 (Cq), 128.6, 128.5, 128.4, 128.4, $128.3,128.3,128.3,128.1,128.0,128.0,127.8,127.7,127.6,127.6$, $127.5\left(\mathrm{CH}_{\text {arom }}\right), 99.7\left(\mathrm{C}-1^{\prime}\right), 91.7(\mathrm{C}-1), 80.4,79.7$ (C-4, C-4'), 77.3 $\left(\mathrm{C}-3^{\prime}\right), 77.1(\mathrm{C}-3), 75.5\left(\mathrm{CH}_{2} \mathrm{Bn}\right), 74.9\left(\mathrm{CH}_{2} \mathrm{Bn}\right), 72.5(\mathrm{C}-2), 71.6$ $\left(\mathrm{CH}_{2} \mathrm{Bn}\right), 69.4\left(\mathrm{C}-2^{\prime}\right), 68.4,67.7\left(\mathrm{C}-5, \mathrm{C}-5^{\prime}\right), 39.0(\mathrm{Cq}), 38.1\left(\mathrm{CH}_{2}\right.$ Lev), $29.9\left(\mathrm{CH}_{3} \mathrm{Lev}\right), 28.2\left(\mathrm{CH}_{2} \mathrm{Lev}\right), 27.2\left(3 \times \mathrm{CH}_{3}\right.$ Piv $), 18.2,17.9$ $\left(2 \times \mathrm{CH}_{3} \mathrm{C}-6, \mathrm{C}-6^{\prime}\right)$; HRMS $[\mathrm{M}+\mathrm{Na}]^{+}$calcd for $\mathrm{C}_{43} \mathrm{H}_{54} \mathrm{O}_{12} \mathrm{Na}$ 785.3508, found 785.3511 .

4-O-Benzyl-2-O-pivaloyl-3-O-(3,4-di-O-benzyl-2-O-levulinoyl- $\alpha$-L-rhamnopyranosyl)-1-( $N$-phenyltrifluoroacetimidoyl)- $\alpha /$ $\beta$-L-rhamnopyranoside (1). To a solution of hemiacetal $19(1.66 \mathrm{~g}$, $2.18 \mathrm{mmol}, 1.0$ equiv) in acetone $(11 \mathrm{~mL})$ at $0{ }^{\circ} \mathrm{C}$ were added $N$ phenyltrifluoroacetimidoyl chloride $(0.41 \mathrm{~mL}, 2.62 \mathrm{mmol}, 1.2$ equiv) followed by $\mathrm{Cs}_{2} \mathrm{CO}_{3}(1.07 \mathrm{~g}, 3.27 \mathrm{mmol}, 1.5$ equiv). The solution was allowed to stir for $3 \mathrm{~h}$, after which it was filtered over Celite and concentrated in vacuo. Purification by column chromatography (PE/ EtOAc, 6:1 $\rightarrow 2: 1$ ) yielded the title compound as a clear yellow oil $(1.81 \mathrm{~g}, 4.15 \mathrm{mmol}, 88 \%)$. Spectroscopic data are reported for the major $(\alpha)$ isomer: $R_{f} 0.67$ (PE/EtOAc, 2/1, v/v); IR (neat) 989, 1028, 1116, 1138, 1207, 1454, 1597, 1716, 1737, 2908, $2976 \mathrm{~cm}^{-1}$; ${ }^{1} \mathrm{H}$ NMR $\left(400 \mathrm{MHz}, \mathrm{CDCl}_{3}\right) \delta 7.49-7.22\left(\mathrm{~m}, 17 \mathrm{H}, \mathrm{CH}_{\text {arom }}\right), 7.08(\mathrm{t}, J=7.5 \mathrm{~Hz}$, $\left.1 \mathrm{H}, \mathrm{CH}_{\text {arom }}\right), 6.81\left(\mathrm{~d}, J=7.7 \mathrm{~Hz}, 2 \mathrm{H}, \mathrm{CH}_{\text {arom }}\right), 6.08(\mathrm{~s}, 1 \mathrm{H}, \mathrm{H}-1), 5.39$ (dd, $\left.J=3.0,1.8 \mathrm{~Hz}, 1 \mathrm{H}, \mathrm{H}-2^{\prime}\right), 5.22(\mathrm{~s}, 1 \mathrm{H}, \mathrm{H}-2), 5.07$ (s, $\left.1 \mathrm{H}, \mathrm{H}-1^{\prime}\right)$, $4.92(\mathrm{~d}, J=11.4 \mathrm{~Hz}, 1 \mathrm{H}, \mathrm{CHH} \mathrm{Bn}), 4.77(\mathrm{~d}, J=10.7 \mathrm{~Hz}, 1 \mathrm{H}, \mathrm{CHH}$ $\mathrm{Bn}), 4.69-4.54\left(\mathrm{~m}, 3 \mathrm{H}, \mathrm{CHH} \mathrm{Bn}, \mathrm{CH}_{2} \mathrm{Bn}\right), 4.47(\mathrm{~d}, J=11.5 \mathrm{~Hz}, 1 \mathrm{H}$, CHH Bn), 4.22-4.15 (m, 1H, H-3), 3.90-3.75 (m, 2H, H-5, H-3'), $3.75-3.63\left(\mathrm{~m}, 1 \mathrm{H}, \mathrm{H}-5^{\prime}\right), 3.49(\mathrm{t}, J=9.5 \mathrm{~Hz}, 1 \mathrm{H}, \mathrm{H}-4), 3.41(\mathrm{t}, J=9.3$ $\left.\mathrm{Hz}, 1 \mathrm{H}, \mathrm{H}-4^{\prime}\right), 2.75-2.60$ (m, $\left.4 \mathrm{H}, 2 \times \mathrm{CH}_{2} \mathrm{Lev}\right), 2.15$ (s, 3H, $\mathrm{CH}_{3}$ Lev), $1.39-1.11\left(\mathrm{~m}, 15 \mathrm{H}, 2 \times \mathrm{CH}_{3} \mathrm{C}-6, \mathrm{C}-6{ }^{\prime}, 3 \times \mathrm{CH}_{3} \mathrm{Piv}\right) ;{ }^{13} \mathrm{C}$ NMR (101 MHz, $\left.\mathrm{CDCl}_{3}\right) \delta 206.2(\mathrm{C}=\mathrm{O}$ Lev), 177.3, $171.9(\mathrm{C}=\mathrm{O}$ Lev, Piv), 143.4, 138.8, 137.9, 137.5 (Cq), 128.8, 128.6, 128.5, 128.4, $128.3,128.2,128.1,127.8,127.6,127.5,124.5,119.4\left(\mathrm{CH}_{\text {arom }}\right), 99.8$ (C-1'), 79.7 (C-4'), 77.3 (C-3), $76.6\left(\mathrm{C}-3^{\prime}\right), 75.8\left(\mathrm{CH}_{2} \mathrm{Bn}\right), 74.9$ $\left(\mathrm{CH}_{2} \mathrm{Bn}\right), 71.7\left(\mathrm{CH}_{2} \mathrm{Bn}\right), 70.5(\mathrm{C}-2), 70.5(\mathrm{C}-5), 69.4\left(\mathrm{C}-2^{\prime}\right), 68.7$ (C-5'), $39.1(\mathrm{Cq}), 38.1\left(\mathrm{CH}_{2} \mathrm{Lev}\right), 29.9\left(\mathrm{CH}_{3} \mathrm{Lev}\right), 28.2\left(\mathrm{CH}_{2} \mathrm{Lev}\right)$, $27.2\left(3 \times \mathrm{CH}_{3}\right.$ Piv $), 18.2,17.9\left(2 \times \mathrm{CH}_{3} \mathrm{C}-6, \mathrm{C}^{\prime} 6^{\prime}\right)$; HRMS $[\mathrm{M}+$ $\mathrm{Na}]^{+}$calcd for $\mathrm{C}_{51} \mathrm{H}_{58} \mathrm{~F}_{3} \mathrm{NO}_{12} \mathrm{Na} 956.3803$, found 956.3809 .

Phenyl 3-O-(3,4-Di-O-benzyl-2-O-levulinoyl- $\alpha$-L-rhamnopyranosyl)-4-O-benzyl-2-O-(3-cyano-2,2-dimethylpropanoyl)-1thio- $\alpha$-L-rhamnopyranoside (18). Imidate donor 14 (4.00 g, 6.51 mmol, 1.1 equiv) and acceptor 16 ( $2.70 \mathrm{~g}, 5.92 \mathrm{mmol}, 1.0$ equiv) were coevaporated two times with anhydrous toluene under an argon atmosphere before being dissolved in distilled DCM $(59 \mathrm{~mL})$, and the mixture was stirred at room temperature for $30 \mathrm{~min}$ over activated molecular sieves $(3 \AA)$. The reaction was cooled to $0{ }^{\circ} \mathrm{C}$, and $\mathrm{TfOH}$ $(0.05 \mathrm{~mL}, 0.59 \mathrm{mmol}, 0.1$ equiv) was added. After $50 \mathrm{~min}$, the reaction was quenched by addition of $1.0 \mathrm{~mL}$ of $\mathrm{Et}_{3} \mathrm{~N}$. The reaction mixture was diluted with $\mathrm{Et}_{2} \mathrm{O}$ and washed with saturated aqueous $\mathrm{NaHCO}_{3}$, $\mathrm{H}_{2} \mathrm{O}$, and saturated aqueous $\mathrm{NaCl}$. The organic layer was dried over $\mathrm{MgSO}_{4}$ and concentrated in vacuo. A quick column purification (PE/ EtOAc, 6:1 $\rightarrow$ 1:1) followed by crystallization from hot EtOH yielded the target disaccharide as a white powder $(4.57 \mathrm{~g}, 5.19 \mathrm{mmol}, 88 \%):{ }^{12}$ mp $106{ }^{\circ} \mathrm{C}$

4-O-Benzyl-2-O-(3-cyano-2,2-dimethylpropanoyl)-3-0-(3,4di-O-benzyl-2-O-levulinoyl- $\alpha$-L-rhamnopyranosyl)- $\alpha / \beta$-L-rhamnopyranoside (20). Compound 18 (0.260 g, $0.295 \mathrm{mmol}, 1.0$ equiv) was dissolved in acetone $/ \mathrm{H}_{2} \mathrm{O}(1.2 \mathrm{~mL} / 0.4 \mathrm{~mL})$ and cooled to $0{ }^{\circ} \mathrm{C}$. NBS ( $0.16 \mathrm{~g}, 0.899 \mathrm{mmol}, 3.0$ equiv) was added, and the reaction was stirred for $3 \mathrm{~h}$, after which TLC analysis showed conversion of the starting material in a lower running spot. The reaction was quenched by addition of saturated aqueous $\mathrm{Na}_{2} \mathrm{~S}_{2} \mathrm{O}_{3}$ and diluted with EtOAc. The organic layer was washed with saturated aqueous $\mathrm{NaHCO}_{3}$, saturated aqueous $\mathrm{NaCl}$, dried over $\mathrm{MgSO}_{4}$, and concentrated in vacuo. Column purification (PE/EtOAc, 4:1 $\rightarrow 1: 1$ ) yielded the hemiacetal $(0.209 \mathrm{~g}, 0.264 \mathrm{mmol}, 89 \%)$. Spectroscopic data are reported for the major $(\alpha)$ isomer: ${ }^{1} \mathrm{H}$ NMR $\left(500 \mathrm{MHz}, \mathrm{CDCl}_{3}\right) \delta$ $7.39-7.20\left(\mathrm{~m}, 15 \mathrm{H}, \mathrm{CH}_{\text {arom }}\right), 5.37\left(\mathrm{dd}, J=3.0,1.9 \mathrm{~Hz}, 1 \mathrm{H}, \mathrm{H}-2^{\prime}\right), 5.06$ (dd, $J=3.1,1.9 \mathrm{~Hz}, 1 \mathrm{H}, \mathrm{H}-2), 5.02\left(\mathrm{~m}, 2 \mathrm{H}, \mathrm{H}-1, \mathrm{H}-1^{\prime}\right), 4.91$ (d, $J=$ $11.2 \mathrm{~Hz}, 1 \mathrm{H}, \mathrm{CHH} \mathrm{Bn}), 4.76(\mathrm{~d}, J=10.9 \mathrm{~Hz}, 1 \mathrm{H}, \mathrm{CHH} \mathrm{Bn}), 4.68-$ $4.54\left(\mathrm{~m}, 3 \mathrm{H}, \mathrm{CH}_{2} \mathrm{Bn}, \mathrm{CHH} \mathrm{Bn}\right), 4.46(\mathrm{~d}, J=11.9 \mathrm{~Hz}, 1 \mathrm{H}, \mathrm{CHH} \mathrm{Bn})$, $4.18(\mathrm{dd}, J=9.5,3.2 \mathrm{~Hz}, 1 \mathrm{H}, \mathrm{H}-2), 4.01-3.89\left(\mathrm{~m}, 1 \mathrm{H}, \mathrm{H}-5\right.$ or $\left.\mathrm{H}-5^{\prime}\right)$, 3.77 (dd, $\left.J=9.2,3.3 \mathrm{~Hz}, 1 \mathrm{H}, \mathrm{H}-3^{\prime}\right), 3.62-3.51$ (m, $1 \mathrm{H}, \mathrm{H}-5$ or $\mathrm{H}-5^{\prime}$ ), $3.39\left(\mathrm{~m}, 2 \mathrm{H}, \mathrm{H}-4, \mathrm{H}-4^{\prime}\right), 2.78-2.58\left(\mathrm{~m}, 4 \mathrm{H}, \mathrm{CH}_{2} \mathrm{Lev}\right), 2.58-2.40(\mathrm{~m}$, $2 \mathrm{H}, \mathrm{CH}_{2}$ PivCN), 2.15 (s, 3H, $\mathrm{CH}_{3} \mathrm{Lev}$ ), 1.37-1.17 (m, 12H, $2 \times$ $\mathrm{CH}_{3}$ PivCN, $\left.2 \times \mathrm{CH}_{3}-6\right) ;{ }^{13} \mathrm{C}$ NMR $\left(126 \mathrm{MHz}, \mathrm{CDCl}_{3}\right) \delta 206.5(\mathrm{C}=$ O Lev), 174.3, 171.9 (C=O Lev, PivCN), 138.6, 137.9, 137.8 (Cq), 128.6, 128.4, 128.4, 128.0, 128.0, 127.9, 127.8, 127.8, 127.7 ( $\left.\mathrm{CH}_{\text {arom }}\right)$, $117.4(\mathrm{CN}), 99.8\left(\mathrm{C}-1^{\prime}\right), 91.4(\mathrm{C}-1), 80.3(\mathrm{C}-4$ or C-4'), 79.7 (C-4 or C-4'), 77.0 (C-3'), $76.6(\mathrm{C}-3), 75.6\left(\mathrm{CH}_{2} \mathrm{Bn}\right), 75.0\left(\mathrm{CH}_{2} \mathrm{Bn}\right), 73.6$ (C-2), $71.3\left(\mathrm{CH}_{2} \mathrm{Bn}\right), 69.1\left(\mathrm{C}-2^{\prime}\right), 68.5\left(\mathrm{C}-5\right.$ or $\left.\mathrm{C}-5^{\prime}\right), 67.8(\mathrm{C}-5$ or C-5'), $41.0(\mathrm{Cq}), 38.1\left(\mathrm{CH}_{2} \mathrm{Lev}\right), 29.9\left(\mathrm{CH}_{3} \mathrm{Lev}\right), 29.6\left(\mathrm{CH}_{2} \mathrm{Lev}\right)$, $28.2\left(\mathrm{CH}_{2}\right.$ PivCN $), 27.8\left(\mathrm{CH}_{2}\right.$ PivCN $), 24.9,24.8\left(2 \times \mathrm{CH}_{3}\right.$ PivCN $)$ 18.1, $17.9\left(2 \times \mathrm{CH}_{3} \mathrm{C}-6, \mathrm{C}-6^{\prime}\right)$.

Anomeric PivCN (20a). Compound 18 (3.65 g, $4.15 \mathrm{mmol}, 1$ equiv) was dissolved in DCM $(40 \mathrm{~mL})$ and cooled to $0{ }^{\circ} \mathrm{C}$. NIS $(1.03$ g, $4.57 \mathrm{mmol}$, 1.1 equiv) was added followed by the dropwise addition of TFA $(0.35 \mathrm{~mL}, 4.57 \mathrm{mmol}, 1.1$ equiv), after which the reaction turned purple. After $340 \mathrm{~min}$, the reaction was quenched by addition of $50 \mathrm{~mL}$ of saturated aqueous $\mathrm{Na}_{2} \mathrm{~S}_{2} \mathrm{O}_{3}$. The mixture was diluted with $60 \mathrm{~mL}$ of DCM and washed with $60 \mathrm{~mL}$ of saturated aqueous $\mathrm{NaHCO}_{3}$. The aqueous layers were extracted $2 \times$ with DCM, and the combined organic layers were washed with saturated aqueous $\mathrm{NaCl}$, dried over $\mathrm{MgSO}_{4}$, and concentrated in vacuo. Column purification $(\mathrm{PE} /$ EtOAc, $4: 1 \rightarrow 1: 1)$ resulted a mixture of 20 and 20 a $73 \%$ yield (2.37 g, $3.01 \mathrm{mmol}): R_{f} 0.35$ (PE/EtOAc, 2/1, v/v); IR (neat) 733, 839, 988, 1040, 1063, 1135, 1363, 1454, 1497, 1717, 1737, 2933, 2976; ${ }^{1} \mathrm{H}$ NMR (500 MHz, Chloroform-d) $\delta 7.41-7.20(\mathrm{~m}, 40 \mathrm{H}), 6.07$ (d, $J$ $=2.2 \mathrm{~Hz}, 1 \mathrm{H}), 5.38(\mathrm{dd}, J=3.3,1.6 \mathrm{~Hz}, 3 \mathrm{H}), 5.13(\mathrm{t}, J=2.8 \mathrm{~Hz}, 1 \mathrm{H})$, $5.10-5.05(\mathrm{~m}, 3 \mathrm{H}), 5.05-5.01(\mathrm{~m}, 3 \mathrm{H}), 4.92(\mathrm{dd}, J=11.2,2.7 \mathrm{~Hz}$, $3 \mathrm{H}), 4.81-4.73(\mathrm{~m}, 3 \mathrm{H}), 4.67-4.54(\mathrm{~m}, 8 \mathrm{H}), 4.53-4.43(\mathrm{~m}, 3 \mathrm{H})$, $4.18(\mathrm{dd}, J=9.5,3.2 \mathrm{~Hz}, 1 \mathrm{H}), 4.13(\mathrm{dd}, J=9.3,3.3 \mathrm{~Hz}, 1 \mathrm{H}), 3.86-$ $3.72(\mathrm{~m}, 4 \mathrm{H}), 3.63-3.49(\mathrm{~m}, 4 \mathrm{H}), 3.45-3.34(\mathrm{~m}, 4 \mathrm{H}), 2.75-2.60(\mathrm{~m}$, $11 \mathrm{H}), 2.56-2.40(\mathrm{~m}, 5 \mathrm{H}), 2.16(\mathrm{~d}, J=2.8 \mathrm{~Hz}, 8 \mathrm{H}), 1.37-1.22(\mathrm{~m}$, $33 \mathrm{H}) ;{ }^{13} \mathrm{C} \mathrm{NMR}\left(126 \mathrm{MHz}, \mathrm{CDCl}_{3}\right) \delta 206.4,206.3,173.9,171.9$, $171.9,155.6,155.2,138.0,138.0,137.9,137.9,137.8,137.3,128.7$, 
$128.7,128.7,128.6,128.6,128.6,128.5,128.5,128.5,128.5,128.5$, $128.5,128.4,128.4,128.4,128.4,128.4,128.4,128.3,128.3,128.3$, $128.3,128.2,128.1,128.0,127.9,127.9,127.9,127.9,127.9,127.9$, $127.8,127.8,127.8,127.8,127.8,127.7,127.7,127.7,127.7,127.7$, 127.6, 127.5, 117.8, 117.4, 117.2, 115.4, 113.1, 75.9, 75.8, 75.6, 75.1, $75.1,74.9,74.8,72.1,71.5,71.4,71.4,71.3,70.6,69.7,69.1,68.9,41.1$, 41.1, 38.2, 38.1, 38.1, 29.8, 29.7, 28.2, 28.2, 28.2, 28.0, 27.9, 27.8, 27.8, 18.1, 18.1, 18.0; HRMS $\left[\mathrm{M}+\mathrm{NH}_{4}\right]^{+}$calcd for $\mathrm{C}_{44} \mathrm{H}_{57} \mathrm{~N}_{2} \mathrm{O}_{12} 805.3906$, found 805.3908 .

4-O-Benzyl-2-O-(3-cyano-2,2-dimethylpropanoyl)-3-O-(3,4di-O-benzyl-2-O-levulinoyl- $\alpha$-L-rhamnopyranosyl)-1-( $N$ phenyltrifluoroacetimidoyl)- $\alpha / \beta$-L-rhamnopyranoside (2). To a solution of mixture hemiacetal 20 and $20 \mathrm{a}(4.15 \mathrm{~g}, 5.27 \mathrm{mmol}, 1$ equiv) in acetone $(26 \mathrm{~mL})$ at $0{ }^{\circ} \mathrm{C}$ were added $N$-phenyltrifluoroacetimidoyl chloride $(0.98 \mathrm{~mL}, 6.32 \mathrm{mmol}, 1.2$ equiv) followed by $\mathrm{Cs}_{2} \mathrm{CO}_{3}(2.57 \mathrm{~g}, 7.9 \mathrm{mmol}, 1.5$ equiv). The solution was allowed to stir overnight, after which it was diluted with EtOAc and washed subsequently with $\mathrm{H}_{2} \mathrm{O}$ and saturated aqueous $\mathrm{NaCl}$. The organic layer was dried over $\mathrm{MgSO}_{4}$ and concentrated in vacuo. Purification by column chromatography (PE/EtOAc, 6:1 $\rightarrow$ 1:1) yielded the title compound as a clear yellow oil $(3.98 \mathrm{~g}, 4.15 \mathrm{mmol}$, 79\%): $R_{f} 0.69$ (PE/EtOAc, 2/1, v/v); IR (neat) 751, 1044, 1137, 1119, 1137, 1364, 1453,1597, 1720,1741, $2935 \mathrm{~cm}^{-1}$. Spectroscopic data are reported for the major $(\alpha)$ isomer: ${ }^{1} \mathrm{H} \mathrm{NMR}\left(500 \mathrm{MHz}, \mathrm{CDCl}_{3}\right) \delta$ 7.39-7.18 (m, 17H, $\left.\mathrm{CH}_{\text {arom }}\right), 7.12-7.04\left(\mathrm{~m}, 1 \mathrm{H}, \mathrm{CH}_{\text {arom }}\right), 6.83-6.77$ $\left(\mathrm{m}, 2 \mathrm{H}, \mathrm{CH}_{\text {arom }}\right), 6.00(\mathrm{~s}, 1 \mathrm{H}, \mathrm{H}-1), 5.38(\mathrm{dd}, J=3.3,1.9 \mathrm{~Hz}, 1 \mathrm{H}, \mathrm{H}-$ $\left.2^{\prime}\right), 5.24$ (dd, $\left.J=3.3,2.0 \mathrm{~Hz}, 1 \mathrm{H}, \mathrm{H}-2\right), 5.06(\mathrm{~d}, J=2.0 \mathrm{~Hz}, 1 \mathrm{H}, \mathrm{H}-1)$, $4.90(\mathrm{~d}, J=11.3 \mathrm{~Hz}, 1 \mathrm{H}, \mathrm{CHH} \mathrm{Bn}), 4.79(\mathrm{~d}, J=10.9 \mathrm{~Hz}, 1 \mathrm{H}, \mathrm{CHH}$ $\mathrm{Bn})$, 4.66-4.54 (m, 3H, CHH, $\left.\mathrm{CH}_{2} \mathrm{Bn}\right), 4.48(\mathrm{dd}, J=11.8,3.2 \mathrm{~Hz}$, $1 \mathrm{H}, \mathrm{CHH} \mathrm{Bn}), 4.18(\mathrm{dd}, J=9.5,3.2 \mathrm{~Hz}, 1 \mathrm{H}, \mathrm{H}-3), 3.92-3.81(\mathrm{~m}, 1 \mathrm{H}$, $\mathrm{H}-5$ ), 3.79 (dd, $\left.J=9.1,3.4 \mathrm{~Hz}, 1 \mathrm{H}, \mathrm{H}-3^{\prime}\right), 3.67-3.57$ (m, 1H, H-5'), $3.53(\mathrm{t}, J=9.5 \mathrm{~Hz}, 1 \mathrm{H}, \mathrm{H}-4), 3.41\left(\mathrm{t}, J=9.3 \mathrm{~Hz}, 1 \mathrm{H}, \mathrm{H}-4^{\prime}\right), 2.72-2.55$ (m, $\left.4 \mathrm{H}, \mathrm{CH}_{2} \mathrm{Lev}\right), 2.54-2.40\left(\mathrm{~m}, 2 \mathrm{H}, \mathrm{CH}_{2} \mathrm{PivCN}\right), 2.14\left(\mathrm{~s}, 3 \mathrm{H}, \mathrm{CH}_{3}\right.$ Lev), $1.39-1.21\left(\mathrm{~m}, 12 \mathrm{H}, 2 \times \mathrm{CH}_{3} \mathrm{PivCN}_{2} 2 \times \mathrm{CH}_{3}-6\right) ;{ }^{13} \mathrm{C} \mathrm{NMR}$ $\left(126 \mathrm{MHz}, \mathrm{CDCl}_{3}\right) \delta 205.8$ (C=O Lev), 173.9, $171.8(\mathrm{C}=\mathrm{O}$ Lev, PivCN), 143.4, 138.8, 138.2, 137.7 (Cq), 128.9, 128.7, 128.6, 128.5, $128.5,128.4,128.4,128.2,128.1,128.0,127.9,127.8,127.8,127.7$, 127.7, 124.7, 124.6, 119.5, 119.4, $117.1\left(\mathrm{CH}_{\text {arom }}\right), 100.0\left(\mathrm{C}-1^{\prime}\right), 93.7$ (C-1), 79.9 (C-4), 79.8 (C-4'), $77.3\left(\mathrm{C}-3^{\prime}\right), 76.9$ (C-3), $75.8\left(\mathrm{CH}_{2}\right.$ $\mathrm{Bn}), 75.1\left(\mathrm{CH}_{2} \mathrm{Bn}\right), 71.8(\mathrm{C}-2), 71.6\left(\mathrm{CH}_{2} \mathrm{Bn}\right), 70.9(\mathrm{C}-5), 69.4(\mathrm{C}-$ $\left.2^{\prime}\right), 68.9\left(\mathrm{C}-5^{\prime}\right), 41.1(\mathrm{Cq}), 38.2\left(\mathrm{CH}_{2} \mathrm{Lev}\right), 29.8\left(\mathrm{CH}_{3} \mathrm{Lev}\right), 28.4$ $\left(\mathrm{CH}_{2} \mathrm{Lev}\right), 28.0\left(\mathrm{CH}_{2}\right.$ PivCN$), 25.0$, $24.9\left(2 \times \mathrm{CH}_{3} \mathrm{PivCN}\right), 18.2(\mathrm{C}-$ 6), $18.0\left(\mathrm{C}-6^{\prime}\right)$; HRMS $\left[\mathrm{M}+\mathrm{NH}_{4}\right]^{+}$calcd $\mathrm{C}_{52} \mathrm{H}_{61} \mathrm{~F}_{3} \mathrm{~N}_{3} \mathrm{O}_{12}$ 976.4202, found 976.4205 .

Methods for Automated Synthesis. The washing solvents were predried $24 \mathrm{~h}$ before use on $4 \AA$ molecular sieves and were of HPLC grade. Activator and deblock solutions were freshly prepared using the predried solvents. Activator: $0.09 \mathrm{M}$ trifluoromethanesulfonic acid in DCE. Deblock: $0.12 \mathrm{M}$ hydrazine acetate in pyridine/AcOH (4/1, v/ $\mathrm{v})$.

Method A. Agitation of the resin during washing. After addition of the appropriate solvent, an argon flow was applied from the bottom of the RV, suspending the resin in solution. The argon flow was applied for $15 \mathrm{~s}$, after which the RV was emptied to the waste.

Method B. Agitation of the resin during coupling/deblock. After addition of the solvent, an argon-flow was applied from the bottom of the RV for $10 \mathrm{~s}$, suspending the resin in the solution. After $10 \mathrm{~s}$, the argon flow was interrupted, and the resin was allowed to settle for $20 \mathrm{~s}$.

Method C. Swelling of the resin. Dry resin was applied to the RV and washed with DCM $(3 \times)$, alternating THF/hexane (3x), THF $(1 \times)$, and DCM $(3 \times)$.

Method D. Coupling cycle. The resin was suspended in DCM. The RV was emptied, followed by addition of the building block solution $(1 \mathrm{~mL})$ while being agitated. The delivery line was flushed with an additional $0.5 \mathrm{~mL}$ of DCM to the RV. The temperature was set to $0{ }^{\circ} \mathrm{C}$ while employing method B. A 10 min pause was started, after which the activator solution $(300 \mu \mathrm{L})$ was added, keeping the temperature below $0{ }^{\circ} \mathrm{C}$. The delivery line was flushed with an additional $0.5 \mathrm{~mL}$ of DCM to the RV. Method B was applied for $1 \mathrm{~h}$, after which the RV was emptied and the mixture was collected in the fraction collector. The resin was washed with DCM $(3 \times 2 \mathrm{~mL})$, and the washes were drained to the fraction collector.

Method E. Deblock cycle. The resin was washed with DMF $(4 \times 3$ $\mathrm{mL})$, running method A. The deblock solution was added $(3 \mathrm{~mL})$, and the temperature was set to $40{ }^{\circ} \mathrm{C}$, followed by a $5 \mathrm{~min}$ incubation applying method $\mathrm{B}$. The temperature was kept at $40{ }^{\circ} \mathrm{C}$, after which the solid support was incubated $10 \mathrm{~min}$ applying protocol $\mathrm{B}$. Then the $\mathrm{RV}$ was emptied to the waste. The resin was washed with DMF $(3 \times 3$ $\mathrm{mL})$, running method $\mathrm{A}$.

Method F. Washing of the resin after coupling. The temperature was set to $20{ }^{\circ} \mathrm{C}$. The resin was washed with $\mathrm{MeOH}(3 \times 2 \mathrm{~mL})$, alternating THF/hexane $(6 \times 2 \mathrm{~mL})$, THF $(2 \times 2 \mathrm{~mL})$, and DCM $(5$ $\times 3 \mathrm{~mL})$, all applying method $\mathrm{A}$.

Method G. Washing of the resin after deblock. The temperature was set to $20^{\circ} \mathrm{C}$. The resin was washed with DMF $(4 \times 3 \mathrm{~mL})$, DCM $(4 \times 3 \mathrm{~mL})$, alternating THF/hexane $(6 \times 3 \mathrm{~mL}), 0.01 \mathrm{M} \mathrm{AcOH}$ in THF $(6 \times 3 \mathrm{~mL})$, THF $(4 \times 3 \mathrm{~mL})$, and DCM $(8 \times 5 \mathrm{~mL})$.

Method H. Suspending the resin for isolation. To the dry resin was added a mixture of $\mathrm{DCM} / \mathrm{MeOH}(3: 2 ; 5 \mathrm{~mL})$, after which the resin was agitated for $15 \mathrm{~s}$. The suspended resin was collected from the $\mathrm{RV}$. The procedure was repeated four times.

\section{Table 1}

\begin{tabular}{|c|c|c|c|c|}
\hline method & $\begin{array}{l}\text { no. of } \\
\text { cycles }\end{array}$ & description & time & temperature \\
\hline $\mathrm{C}$ & 1 & swelling of the resin & & $\mathrm{rt}$ \\
\hline D & 1 & $\begin{array}{l}\text { coupling: } 3 \text { equiv of donor, } \\
0.3 \text { equiv of TfOH }\end{array}$ & $60 \mathrm{~min}$ & $0{ }^{\circ} \mathrm{C}$ \\
\hline $\mathrm{E}$ & 3 & $\begin{array}{l}\text { washing of the resin after } \\
\text { coupling }\end{array}$ & & $20^{\circ} \mathrm{C}$ \\
\hline $\mathrm{F}$ & 3 & $\begin{array}{l}\text { deblock: } 8 \text { equiv of } \mathrm{H}_{2} \mathrm{NNH}_{2} \text {. } \\
\text { AcOH }\end{array}$ & $15 \mathrm{~min}$ & $40{ }^{\circ} \mathrm{C}$ \\
\hline G & 1 & $\begin{array}{l}\text { washing of the resin after } \\
\text { deblock }\end{array}$ & & $20{ }^{\circ} \mathrm{C}$ \\
\hline
\end{tabular}

Automated Synthesis of Rhamnose Fragments. The reaction vessel was charged with carboxy polystyrene 3 (100 mg, $45 \mu \mathrm{mol})$, and method $\mathrm{C}$ was applied to prepare the resin for synthesis. Then methods $\mathrm{D}$ and $\mathrm{E}$ for coupling and deprotection were repeated 5 times for decasaccharide $\mathbf{2 2}$ and 8 times to obtain hexadecasaccharide 23 . Method $\mathrm{H}$ was used to isolate the resin from the reaction vessel. The resin was dried overnight. After cleavage from the solid support, the rhamnose fragments were analyzed by LC/MS.

Decarhamnoside (22). The dry resin was charged in a syringe with a screw cap and suspended in THF/MeOH $(2 \mathrm{~mL}, 1: 1)$ followed by addition of $\mathrm{NaOMe}(0.08 \mathrm{~mL}, 0.54 \mathrm{M} \mathrm{NaOMe} / \mathrm{MeOH}, 1$ equiv). The resin was shaken overnight. The solution was filtered, and the remaining resin was washed with $\mathrm{MeOH}(5 \times 4 \mathrm{~mL})$. The combined filtrate and washes were neutralized with 2-3 drops of $\mathrm{AcOH}$ and concentrated in vacuo. The cleavage procedure was repeated once to obtain the mixture containing 22 as an amorphous solid $(0.161 \mathrm{~g})$.

Hexadecarhamnoside (23). The dry resin was charged in a syringe with a screw cap and suspended in THF/MeOH $(2 \mathrm{~mL}, 1: 1)$ followed by addition of $\mathrm{NaOMe}(0.08 \mathrm{~mL}, 0.54 \mathrm{M} \mathrm{NaOMe} / \mathrm{MeOH}, 1$ equiv). The resin was shaken overnight. The solution was filtered, and the remaining resin was washed with $\mathrm{MeOH}(5 \times 4 \mathrm{~mL})$. The combined filtrate and washes were neutralized with 2-3 drops of $\mathrm{AcOH}$ and concentrated in vacuo. The cleavage procedure was repeated once to obtain the mixture containing $\mathbf{2 3}$ as an amorphous solid $(0.198 \mathrm{~g})$.

General Procedure for Complete Removal of PivCN Groups. The crude rhamnoside mixture was dissolved in $\mathrm{THF} / \mathrm{MeOH}(0.6-2$ $\mathrm{mL}, 1: 1)$ and treated with a $0.54 \mathrm{M} \mathrm{NaOMe} / \mathrm{MeOH}$ (0.7-2 equiv) solution. The reaction was monitored by LC/MS and allowed to stir overnight. An additional $0.54 \mathrm{M} \mathrm{NaOMe} / \mathrm{MeOH}$ was added when LC/MS analysis indicated incomplete removal of the PivCN groups. If the deprotection proceeded slowly, the mixture was neutralized, concentrated in vacuo, and treated with the conditions mentioned vide 
supra. Purification by size exclusion chromatography (LH20, eluted with $\mathrm{DCM} / \mathrm{MeOH}, 1 / 1, \mathrm{v} / \mathrm{v}$ ) or HPLC yielded the target rhamnoside fragments.

Semiprotected Decarhamnoside (26). The crude rhamnoside mixture $(0.162 \mathrm{~g})$ was dissolved in $\mathrm{THF} / \mathrm{MeOH}(4 \mathrm{~mL}, 1: 1)$ and treated with $0.16 \mathrm{~mL}$ of $\mathrm{NaOMe}(0.54 \mathrm{M} \mathrm{NaOMe} / \mathrm{MeOH})$. After overnight stirring, LC/MS analysis indicated incomplete removal of the PivCN groups, after which the mixture was neutralized with $\mathrm{AcOH}$ and concentrated in vacuo. The mixture was redissolved in THF/ $\mathrm{MeOH}(2 \mathrm{~mL}, 1: 1)$, treated with $0.1 \mathrm{~mL}$ of $\mathrm{NaOMe}(0.54 \mathrm{M}$ $\mathrm{NaOMe} / \mathrm{MeOH}$ ), and stirred overnight. After overnight stirring, 0.08 $\mathrm{mL}$ of $\mathrm{NaOMe}(0.54 \mathrm{M} \mathrm{NaOMe} / \mathrm{MeOH})$ was added, followed by 0.16 $\mathrm{mL}$ of $\mathrm{NaOMe}(0.54 \mathrm{M} \mathrm{NaOMe} / \mathrm{MeOH})$ after $6.5 \mathrm{~h}$, whereafter LC/ MS analysis indicated complete removal of the PivCN groups. The mixture was neutralized with $\mathrm{AcOH}$ and concentrated in vacuo and coevaporated once with toluene. The target decarhamnoside was isolated using RP-HPLC purification (C4 column, gradient $70 \rightarrow 90$, $20 \mathrm{~min}$ per run) as a white solid ( $37.4 \mathrm{mg}, 11.8 \mu \mathrm{mol}, 26 \%$ based on $45 \mu$ mol resin): IR (neat) 736, 1028, 1041, 1070, 1126, 1207, 1361, 1454, 1496, 1681, 2927, 3030, $3377 \mathrm{~cm}^{-1}$; ${ }^{1} \mathrm{H}$ NMR $(500 \mathrm{MHz}$, $\left.\mathrm{MeCN}-d_{3}, T=328 \mathrm{~K}\right) \delta 7.42-7.18\left(\mathrm{~m}, 84 \mathrm{H}, \mathrm{CH}_{\text {arom }}\right), 5.11-5.06(\mathrm{~m}$, $4 \mathrm{H}, \mathrm{CH}_{2}$ linker-CBz, $\left.2 \times \mathrm{H}-1\right), 5.04(\mathrm{~s}, 1 \mathrm{H}, \mathrm{H}-1), 4.98(\mathrm{~s}, 1 \mathrm{H}, \mathrm{H}-1)$, 4.87-4.49 (m, 33H), $4.45\left(\mathrm{~s}, 2 \mathrm{H}, \mathrm{CH}_{2}\right.$ linker), 4.05-3.95 (m, $\left.8 \mathrm{H}\right)$, 3.95-3.77 (m, 14H), $3.72(\mathrm{~m}, 4 \mathrm{H}), 3.66-3.51(\mathrm{~m}, 2 \mathrm{H}), 3.52-3.34$ $(\mathrm{m}, 9 \mathrm{H}), 3.32(\mathrm{~s}, 1 \mathrm{H}), 3.21\left(\mathrm{t}, J=7.3 \mathrm{~Hz}, 2 \mathrm{H}, \mathrm{CH}_{2}\right.$ linker $), 3.06(\mathrm{~s}$, $5 \mathrm{H}), 1.53-1.46\left(\mathrm{~m}, 4 \mathrm{H}, \mathrm{CH}_{2}\right.$ linker), 1.35-1.24 ( $\mathrm{m}, 7 \mathrm{H}, \mathrm{CH}_{2}$ linker, $\left.\mathrm{CH}_{3}-6\right), 1.24-1.11\left(\mathrm{~m}, 17 \mathrm{H}, \mathrm{CH}_{3}-6\right), 1.10-1.00\left(\mathrm{~m}, 10 \mathrm{H}, \mathrm{CH}_{3}-6\right)$; ${ }^{13} \mathrm{C}$ NMR (126 MHz, MeCN-d $\left.d_{3}, T=328 \mathrm{~K}\right) \delta 140.1(\mathrm{Cq}), 129.6$, $129.5,129.5,129.4,129.4,129.3,129.2,129.2,129.1,129.0,129.0$, $128.8,128.8,128.7,128.7,128.3,128.0\left(\mathrm{CH}_{\text {arom }}\right), 103.2,103.0,103.0$, 103.0, 102.4, 101.2, 101.0 (10x C-1), 81.5, 81.4, 81.3, 81.2, 81.0, 80.9, $80.8,80.8,80.0(10 \times \mathrm{C}-3,10 \times \mathrm{C}-4), 77.4,77.3,77.2(\mathrm{C}-2), 76.1$, 76.0, 75.9 $\left(\mathrm{CH}_{2}\right), 72.9,72.3,72.2\left(\mathrm{CH}_{2}\right), 72.1(10 \times \mathrm{C}-2), 69.6,69.6$, 69.3, 69.0, 68.3, 67.8 (10× C-5), $64.8\left(\mathrm{CH}_{2}\right), 51.5\left(\mathrm{CH}_{2}\right), 30.1$ $\left(\mathrm{CH}_{2}\right), 24.4\left(\mathrm{CH}_{2}\right), 18.8,18.7,18.7,18.6\left(10 \times \mathrm{CH}_{3}-6\right)$; HRMS [M + $\left.\mathrm{NH}_{4}\right]^{+}$calcd for $\mathrm{C}_{186} \mathrm{H}_{221} \mathrm{~N}_{2} \mathrm{O}_{44} 3188.5173$, found 3188.5121 .

Semiprotected Hexadecarhamnoside (29). The crude rhamnoside mixture $(0.199 \mathrm{~g})$ was dissolved in THF/MeOH $(2 \mathrm{~mL}, 1: 1)$ and treated with $0.10 \mathrm{~mL}$ of $\mathrm{NaOMe}(0.54 \mathrm{M} \mathrm{NaOMe} / \mathrm{MeOH})$. After $2 \mathrm{~h}$, an additional $0.24 \mathrm{~mL}$ of $\mathrm{NaOMe}(0.54 \mathrm{M} \mathrm{NaOMe} / \mathrm{MeOH})$ was added, followed by another $0.10 \mathrm{~mL}$ after $4 \mathrm{~h}$. After overnight stirring, LC/MS analysis indicated complete removal of all PivCN groups, after which the mixture was neutralized by addition of 2-3 drops $\mathrm{AcOH}$. The mixture was concentrated in vacuo and coevapotrated with toluene once. The target hexadecarhamnoside was isolated using RPHPLC purification (C4 column, gradient $70 \rightarrow 90,20$ min per run) as a white solid (20.3 mg, $4.2 \mu \mathrm{mol}, 9.3 \%$ based on $45 \mu \mathrm{mol}$ resin): IR (neat) $750,1051,1129,1454,1671,2917 \mathrm{~cm}^{-1}$; ${ }^{1} \mathrm{H}$ NMR $(600 \mathrm{MHz}$, $\left.\mathrm{MeCN}-d_{3}, T=328 \mathrm{~K}\right) \delta 7.39(\mathrm{~d}, J=7.4 \mathrm{~Hz}, 2 \mathrm{H}), 7.36-7.17(\mathrm{~m}$, $129 \mathrm{H}), 5.12-5.04(\mathrm{~m}, 8 \mathrm{H}), 5.03(\mathrm{~d}, J=1.9 \mathrm{~Hz}, 1 \mathrm{H}), 4.97(\mathrm{~d}, J=1.7$ $\mathrm{Hz}, 1 \mathrm{H}), 4.87-4.47(\mathrm{~m}, 60 \mathrm{H}), 4.44(\mathrm{~s}, 2 \mathrm{H}), 4.08-3.93(\mathrm{~m}, 16 \mathrm{H})$, $3.94-3.80(\mathrm{~m}, 24 \mathrm{H}), 3.80-3.63(\mathrm{~m}, 8 \mathrm{H}), 3.63-3.51(\mathrm{~m}, 4 \mathrm{H}), 3.51-$ $3.34(\mathrm{~m}, 16 \mathrm{H}), 3.33-3.24(\mathrm{~m}, 2 \mathrm{H}), 3.20(\mathrm{t}, J=7.3 \mathrm{~Hz}, 2 \mathrm{H}), 3.17-$ $2.79(\mathrm{~m}, 9 \mathrm{H}), 1.55-1.43(\mathrm{~m}, 4 \mathrm{H}), 1.36-1.22(\mathrm{~m}, 8 \mathrm{H}), 1.21-1.10(\mathrm{~m}$, $29 \mathrm{H}), 1.09-0.95(\mathrm{~m}, 21 \mathrm{H}) ;{ }^{13} \mathrm{C}$ NMR $\left(151 \mathrm{MHz}, \mathrm{MeCN}-d_{3}, T=328\right.$ K) $\delta 140.1,140.0,140.0,140.0,129.6,129.5,129.4,129.4,129.4$, $129.3,129.3,129.2,129.1,129.1,129.0,128.9,128.9,128.8,128.7$, $128.7,128.7,128.6,128.6,128.2,127.9,118.3,103.1,103.0,102.9$, $102.9,102.9,102.3,102.3,100.9,81.4,81.3,81.3,81.2,81.2,81.1,81.0$, $80.8,80.7,79.9,77.3,77.3,77.2,77.0,76.0,75.9,75.9,72.8,72.8,72.2$, $72.1,72.0,69.5,69.5,69.2,68.9,64.7,51.4,30.0,24.3,18.8,18.7,18.6$, $18.6,18.6,18.5,1.8,1.6,1.5,1.4,1.3,1.2,1.1,0.9$; MALDI-TOF $m / z$ $[\mathrm{M}+\mathrm{Na}]^{+}$calcd for $\mathrm{C}_{285} \mathrm{H}_{331} \mathrm{NO}_{68} \mathrm{Na}$ 4878.2, found 4884.9.

General Procedure for the Hydrogenation. The oligosaccharide was dissolved in $\mathrm{H}_{2} \mathrm{O} / \mathrm{THF} / \mathrm{tBOH}$ (3:1.3:1.3) followed by addition of several drops of $\mathrm{AcOH}$. The solution was purged with $\mathrm{N}_{2}$ for $5 \mathrm{~min}$, after which $\mathrm{Pd}(\mathrm{OH})_{2} / \mathrm{C}(10-20 \mathrm{mg})$ was added followed by another purge with $\mathrm{N}_{2}$ for $5 \mathrm{~min}$. The solution was purged for 5 min with $\mathrm{H}_{2}$ and kept under a $\mathrm{H}_{2}$ atmosphere overnight. The mixture was filtered over a Whatmann filter and rinsed with the $\mathrm{H}_{2} \mathrm{O}$ /THF/ $t \mathrm{BuOH}$ mixture and $\mathrm{H}_{2} \mathrm{O}$.

Decarhamnoside (5). Compound $26(19.1 \mathrm{mg}, 6 \mu \mathrm{mol})$ was dissolved in $\mathrm{H}_{2} \mathrm{O} / \mathrm{THF} / \mathrm{tBuOH}$ (1.6 mL, 3:1.3:1.3), and 4-5 drops of AcOH were added. The solution was purged with $\mathrm{N}_{2}$ for 5 min, after which $\mathrm{Pd}(\mathrm{OH})_{2} / \mathrm{C}(20 \mathrm{mg})$ was added, followed by another purge with $\mathrm{N}_{2}$ for $5 \mathrm{~min}$. The solution was purged for $5 \mathrm{~min}$ with $\mathrm{H}_{2}$ and kept under a $\mathrm{H}_{2}$ atmosphere overnight. After overnight stirring, the mixture was filtered through a Whatmann filter and concentrated in vacuo. Purification by size exclusion chromatography (LH20, eluted with $\mathrm{MeOH} / \mathrm{H}_{2} \mathrm{O}, 9 / 1, \mathrm{v} / \mathrm{v}$ ) and analysis by ${ }^{1} \mathrm{H}$ NMR indicated the presence of aromatic signals. The hydrogenation procedure was repeated once. Purification using gel filtration (HW-40, eluted with $\mathrm{NH}_{4} \mathrm{OAc}$ ) and subsequent lyophilization yielded the target decarhamnoside as a white powder $(5.3 \mathrm{mg}, 3.4 \mu \mathrm{mol}, 57 \%):{ }^{1} \mathrm{H}$ NMR (500 $\left.\mathrm{MHz}, \mathrm{D}_{2} \mathrm{O}\right) \delta 5.11-5.06(\mathrm{~m}, 4 \mathrm{H}), 4.93(\mathrm{~d}, J=1.8 \mathrm{~Hz}, 1 \mathrm{H}), 4.87-4.81$ $(\mathrm{m}, 4 \mathrm{H}), 4.05(\mathrm{~m}, 4 \mathrm{H}), 3.99-3.93(\mathrm{~m}, 5 \mathrm{H}), 3.91-3.87(\mathrm{~m}, 1 \mathrm{H})$, 3.86-3.80 (m, 4H), 3.78-3.70 (m, 9H), 3.70-3.56 (m, 8H), 3.49$3.31(\mathrm{~m}, 11 \mathrm{H}), 2.89(\mathrm{t}, J=7.6 \mathrm{~Hz}, 2 \mathrm{H}), 1.64-1.52(\mathrm{~m}, 4 \mathrm{H}), 1.42-$ $1.29(\mathrm{~m}, 2 \mathrm{H}), 1.24-1.09(\mathrm{~m}, 30 \mathrm{H}) ;{ }^{13} \mathrm{C}$ NMR $\left(126 \mathrm{MHz}, \mathrm{D}_{2} \mathrm{O}\right) \delta$ 102.5 , 102.2, 102.2, 101.0, 101.0, 100.9, 99.7, 78.3, 78.2, 78.1, 77.7, 77.6, 77.6, 72.3, 72.1, 71.9, 71.8, 71.5, 70.3, 70.3, 70.1, 70.1, 70.1, 70.0, 69.5, 69.5, 69.4, 69.3, 68.8, 67.6, 39.5, 28.2, 26.7, 22.8, 22.6, 16.9, 16.8, 16.8, 16.7, 16.6; HRMS $[\mathrm{M}+\mathrm{H}]^{+}$calcd for $\mathrm{C}_{65} \mathrm{H}_{114} \mathrm{NO}_{41}$ 1564.6861, found 1564.6873 .

Hexadecarhamnoside (8). Compound $29(7.2 \mathrm{mg}, 1.5 \mu \mathrm{mol})$ was dissolved in $\mathrm{H}_{2} \mathrm{O} / \mathrm{THF} / \mathrm{tBOH}(1.0 \mathrm{~mL}, 3: 1.3: 1.3)$, and $4-5$ drops of $\mathrm{AcOH}$ were added. The solution was purged with $\mathrm{N}_{2}$ for 5 min, after which $\mathrm{Pd}(\mathrm{OH})_{2} / \mathrm{C}(8 \mathrm{mg})$ was added, followed by another purge with $\mathrm{N}_{2}$ for $5 \mathrm{~min}$. The solution was purged for 5 min with $\mathrm{H}_{2}$ and kept under a $\mathrm{H}_{2}$ atmosphere overnight. After overnight stirring, the mixture was filtered through a Whatmann filter and concentrated in vacuo. Purification using gel filtration (HW-40, eluted with $\mathrm{NH}_{4} \mathrm{OAc}$ ) and subsequent lyophilization yielded the target hexadecarhamnoside as a white powder $(1.8 \mathrm{mg}, 0.75 \mu \mathrm{mol}, 50 \%):{ }^{1} \mathrm{H}$ NMR $\left(500 \mathrm{MHz}, \mathrm{D}_{2} \mathrm{O}\right) \delta 5.26-5.12(\mathrm{~m}, 7 \mathrm{H}), 5.04(\mathrm{~d}, 2 \mathrm{H}, J=1.5 \mathrm{~Hz}), 4.95$ $(\mathrm{s}, 9 \mathrm{H}), 4.16(\mathrm{~s}, 7 \mathrm{H}), 4.07(\mathrm{~s}, 8 \mathrm{H}), 3.99(\mathrm{~s}, 1 \mathrm{H}), 3.95(\mathrm{~m}, 7 \mathrm{H}), 3.88-$ $3.68(\mathrm{~m}, 25 \mathrm{H}), 3.59-3.43(\mathrm{~m}, 17 \mathrm{H}), 2.99(\mathrm{t}, 2 \mathrm{H}, J=7.5 \mathrm{~Hz}), 1.74-$ $1.59(\mathrm{~m}, 4 \mathrm{H}), 1.52-1.39(\mathrm{~m}, 2 \mathrm{H}), 1.35-1.20(\mathrm{~m}, 48 \mathrm{H}) ;{ }^{13} \mathrm{C}$ NMR $\left(126 \mathrm{MHz}, \mathrm{D}_{2} \mathrm{O}\right) \delta 102.4,102.1,102.1,100.9,100.9,99.6,78.2,78.1$, 78.0, 77.6, 77.4, 72.2, 72.0, 71.7, 71.4, 70.2, 70.1, 70.0, 70.0, 69.9, 69.4 69.4, 69.3, 69.2, 68.7, 67.5, 39.4, 28.1, 26.6, 23.3, 22.5, 16.8, 16.7, 16.7, 16.6, 16.5; HRMS $[\mathrm{M}+\mathrm{H}]^{+}$calcd for $\mathrm{C}_{101} \mathrm{H}_{174} \mathrm{NO}_{65}$ 2442.0369, found 2442.0361 .

Isolation of Deletion Fragments. Octarhamnoside (25). Obtained as byproduct from $22(10.4 \mathrm{mg}, 4.0 \mu \mathrm{mol}):{ }^{1} \mathrm{H}$ NMR $\left(500 \mathrm{MHz}, \mathrm{MeCN}-d_{3}, T=328 \mathrm{~K}\right) \delta 7.42-7.37(\mathrm{~m}, 2 \mathrm{H}), 7.36-7.13$ (m, 67H), 5.13-5.07 (m, 4H), $5.04(\mathrm{~d}, J=2.1 \mathrm{~Hz}, 1 \mathrm{H}), 4.98(\mathrm{~d}, J=$ $1.8 \mathrm{~Hz}, 1 \mathrm{H}), 4.88-4.73(\mathrm{~m}, 10 \mathrm{H}), 4.72-4.52(\mathrm{~m}, 20 \mathrm{H}), 4.45(\mathrm{~s}, 2 \mathrm{H})$, 4.06-3.96 (m, 7H), 3.95-3.78 (m, 13H), 3.78-3.67 (m, 3H), 3.63$3.51(\mathrm{~m}, 2 \mathrm{H}), 3.51-3.36(\mathrm{~m}, 8 \mathrm{H}), 3.37-3.28(\mathrm{~m}, 1 \mathrm{H}), 3.22(\mathrm{t}, J=7.3$ $\mathrm{Hz}, 2 \mathrm{H}), 3.05(\mathrm{~s}, 5 \mathrm{H}), 1.56-1.44(\mathrm{~m}, 4 \mathrm{H}), 1.30(\mathrm{~s}, 6 \mathrm{H}), 1.24-1.12$ (m, 15H), $1.11-1.02(\mathrm{~m}, 9 \mathrm{H}) ;{ }^{13} \mathrm{C}$ NMR $\left(126 \mathrm{MHz}, \mathrm{MeCN}-d_{3}, T=\right.$ 328 K) $\delta 140.1,129.6,129.6,129.5,129.4,129.4,129.3,129.3,129.2$, $129.2,129.1,129.1,129.0,129.0,128.9,128.8,128.8,128.7,128.7$, $128.7,128.6,128.3,128.3,127.9,111.2,103.1,102.9,102.3,101.0$, 81.4, 81.3, 81.3, 81.3, 81.1, 81.1, 81.0, 80.9, 80.8, 79.9, 77.2, 77.1, 76.1, 75.9, 75.9, 72.8, 72.8, 72.3, 72.1, 72.1, 69.6, 69.5, 69.2, 69.0, 68.2, 67.7, 64.8, 18.8, 18.7, 18.6; HRMS $[\mathrm{M}+\mathrm{H}]^{+}$calcd For $\mathrm{C}_{153} \mathrm{H}_{180} \mathrm{NO}_{36}$ 2608.2246, found 2608.2273.

Deprotected Octarhamnoside (4). White solid after general hydrogenation procedure $(1.35 \mathrm{mg}, 1.06 \mu \mathrm{mol}, 69 \%):{ }^{1} \mathrm{H}$ NMR $\left(500 \mathrm{MHz}, \mathrm{D}_{2} \mathrm{O}\right) \delta 5.24-5.13(\mathrm{~m}, 3 \mathrm{H}), 5.03(\mathrm{~s}, 1 \mathrm{H}), 4.94(\mathrm{~s}, 3 \mathrm{H})$ $4.15(\mathrm{~s}, 3 \mathrm{H}), 4.06(\mathrm{~s}, 4 \mathrm{H}), 3.98(\mathrm{~s}, 1 \mathrm{H}), 3.97-3.90(\mathrm{~m}, 3 \mathrm{H}), 3.87-$ $3.66(\mathrm{~m}, 14 \mathrm{H}), 3.60-3.39(\mathrm{~m}, 9 \mathrm{H}), 2.99(\mathrm{t}, J=7.4 \mathrm{~Hz}, 2 \mathrm{H}), 1.76-$ $1.59(\mathrm{~m}, 4 \mathrm{H}), 1.54-1.37(\mathrm{~m}, 2 \mathrm{H}), 1.36-1.18(\mathrm{~m}, 24 \mathrm{H}) ;{ }^{13} \mathrm{C}$ NMR $\left(126 \mathrm{MHz}, \mathrm{D}_{2} \mathrm{O}\right) \delta 109.8,102.5,102.2$, 100.9, 99.7, 78.1, 77.6, 72.4, $72.1,71.9,71.8,71.5,70.3,70.0,69.5,69.4,69.3,68.8,67.6,59.3,39.5$, 28.2, 26.7, 22.6, 16.8, 16.8, 9.3; HRMS $[\mathrm{M}+\mathrm{H}]^{+}$calcd For $\mathrm{C}_{53} \mathrm{H}_{94} \mathrm{NO}_{33}$ 1272.5703, found 1272.5714 . 
Dodecarhamnoside (27). Obtained as byproduct from 23 (10.3 $\mathrm{mg}, 2.8 \mu \mathrm{mol}):{ }^{1} \mathrm{H}$ NMR $\left(600 \mathrm{MHz}, \mathrm{MeCN}-d_{3}, T=328 \mathrm{~K}\right) \delta 7.42-$ $7.17(\mathrm{~m}, 99 \mathrm{H}), 5.12-5.05(\mathrm{~m}, 6 \mathrm{H}), 5.03(\mathrm{~d}, J=2.1 \mathrm{~Hz}, 1 \mathrm{H}), 4.97(\mathrm{~d}, J$ $=2.0 \mathrm{~Hz}, 1 \mathrm{H}), 4.87-4.48(\mathrm{~m}, 44 \mathrm{H}), 4.45(\mathrm{~s}, 2 \mathrm{H}), 4.05-3.94(\mathrm{~m}$, $12 \mathrm{H}), 3.93-3.76(\mathrm{~m}, 19 \mathrm{H}), 3.76-3.66(\mathrm{~m}, 6 \mathrm{H}), 3.64-3.51(\mathrm{~m}, 3 \mathrm{H})$, $3.50-3.35(\mathrm{~m}, 13 \mathrm{H}), 3.33-3.26(\mathrm{~m}, 1 \mathrm{H}), 3.26(\mathrm{~s}, 1 \mathrm{H}), 3.21(\mathrm{t}, J=7.3$ $\mathrm{Hz}, 3 \mathrm{H}), 1.54-1.44(\mathrm{~m}, 4 \mathrm{H}), 1.29(\mathrm{~s}, 9 \mathrm{H}), 1.23-0.98(\mathrm{~m}, 36 \mathrm{H}) ;{ }^{13} \mathrm{C}$ NMR $\left(151 \mathrm{MHz}, \mathrm{CD}_{3} \mathrm{CN}\right) \delta 143.0,140.3,140.1,140.1,140.0,140.0$, $140.0,140.0,139.8,137.3,129.6,129.5,129.4,129.4,129.4,129.4$, $129.4,129.4,129.3,129.3,129.3,129.3,129.2,129.2,129.1,129.1$, $129.1,129.0,129.0,129.0,128.9,128.8,128.8,128.7,128.7,128.7$, $128.7,128.6,128.6,103.1,103.0,102.9,102.9,102.9,102.9,102.9$, $102.3,102.3,101.0,81.4,81.3,81.2,81.2,81.2,81.1,81.0,80.9,80.8$, 76.1, 76.0, 76.0, 75.9, 75.9, 75.9, 72.8, 72.8, 72.7, 72.2, 69.5, 69.5, 68.2, $67.7,64.7,30.0,27.7,24.3,18.7,18.6,18.6,18.6,18.5$; MALDI-TOF $m / z[\mathrm{M}+\mathrm{Na}]^{+}$calcd for $\mathrm{C}_{219} \mathrm{H}_{255} \mathrm{NO}_{52} \mathrm{Na} 3753.7$, found 3756.4.

Deprotected Dodecarhamnoside (6). White solid after general hydrogenation procedure $(0.51 \mathrm{mg}, 0.27 \mu \mathrm{mol}, 27 \%):{ }^{1} \mathrm{H}$ NMR (500 $\left.\mathrm{MHz}, \mathrm{D}_{2} \mathrm{O}\right) \delta 5.24-5.15(\mathrm{~m}, 5 \mathrm{H}), 5.05-5.00(\mathrm{~m}, 1 \mathrm{H}), 4.94(\mathrm{~s}, 6 \mathrm{H})$, $4.14(\mathrm{~d}, J=2.4 \mathrm{~Hz}, 6 \mathrm{H}), 4.06(\mathrm{~s}, 7 \mathrm{H}), 3.98(\mathrm{~s}, 1 \mathrm{H}), 3.97-3.88(\mathrm{~m}$, $7 \mathrm{H}), 3.87-3.65(\mathrm{~m}, 24 \mathrm{H}), 3.61-3.35(\mathrm{~m}, 16 \mathrm{H}), 3.04-2.93(\mathrm{~m}, 2 \mathrm{H})$, $1.76-1.60(\mathrm{~m}, 6 \mathrm{H}), 1.53-1.39(\mathrm{~m}, 2 \mathrm{H}), 1.35-1.18$ (m, 36H); HRMS $[\mathrm{M}+\mathrm{H}]^{+}$calcd for $\mathrm{C}_{77} \mathrm{H}_{134} \mathrm{NO}_{49} 1856.8019$, found 1856.8064 .

Tetradecarhamnoside (28). Obtained as byproduct from 23 (20 $\mathrm{mg}, 4.65 \mu \mathrm{mol}):{ }^{1} \mathrm{H} \mathrm{NMR}\left(600 \mathrm{MHz}, \mathrm{MeCN}-d_{3}, T=328 \mathrm{~K}\right) \delta 7.48-$ $7.14(\mathrm{~m}, 114 \mathrm{H}), 5.10-5.05(\mathrm{~m}, 6 \mathrm{H}), 5.03(\mathrm{~d}, J=2.1 \mathrm{~Hz}, 1 \mathrm{H}), 4.97(\mathrm{~d}$, $J=2.0 \mathrm{~Hz}, 1 \mathrm{H}), 4.87-4.48(\mathrm{~m}, 46 \mathrm{H}), 4.45(\mathrm{~s}, 2 \mathrm{H}), 4.06-3.94(\mathrm{~m}$, $12 \mathrm{H}), 3.94-3.77(\mathrm{~m}, 20 \mathrm{H}), 3.71(\mathrm{~m}, 6 \mathrm{H}), 3.64-3.50(\mathrm{~m}, 3 \mathrm{H}), 3.50-$ $3.35(\mathrm{~m}, 13 \mathrm{H}), 3.30(\mathrm{~s}, 1 \mathrm{H}), 3.21(\mathrm{t}, J=7.3 \mathrm{~Hz}, 2 \mathrm{H}), 3.16-3.01(\mathrm{~m}$, $7 \mathrm{H}), 1.50(\mathrm{~m}, 4 \mathrm{H}), 1.36-1.24(\mathrm{~m}, 5 \mathrm{H}), 1.24-0.97(\mathrm{~m}, 42 \mathrm{H}) ;{ }^{13} \mathrm{C}$ NMR $\left(151 \mathrm{MHz}, \mathrm{CD}_{3} \mathrm{CN}\right) \delta 140.3,140.1,140.1,140.0,140.0,140.0$, $140.0,140.0,139.8,137.3,129.5,129.5,129.4,129.4,129.4,129.4$, $129.4,129.3,129.3,129.3,129.2,129.2,129.1,129.1,129.1,129.1$, $129.0,129.0,129.0,128.8,128.8,128.7,128.7,128.7,128.7,128.7$, $128.6,128.6,128.6,103.1,103.0,102.9,102.9,102.9,102.9,102.3$, $102.3,101.0,81.3,81.2,81.2,81.1,80.7,76.1,76.0,75.9,75.9,75.9$, 75.9, 72.8, 72.8, 72.7, 72.2, 72.1, 69.5, 69.5, 68.2, 67.7, 64.7, 30.0, 24.3, 18.6; MALDI-TOF $m / z[\mathrm{M}+\mathrm{K}]^{+}$calcd for $\mathrm{C}_{252} \mathrm{H}_{293} \mathrm{KNO}_{60} 4332.0$, found 4337.0.

Deprotected Tetradecarhamnoside (7). White solid after general hydrogenation procedure (4.7 mg, $2.2 \mu \mathrm{mol}, 92 \%):{ }^{1} \mathrm{H}$ NMR (500 $\left.\mathrm{MHz}, \mathrm{D}_{2} \mathrm{O}\right) \delta 5.23-5.14(\mathrm{~m}, 6 \mathrm{H}), 5.04(\mathrm{~d}, J=1.7 \mathrm{~Hz}, 1 \mathrm{H}), 4.98-4.90$ (m, 7H), 4.17-4.13 (m, 6H), $4.07(\mathrm{~s}, 7 \mathrm{H}), 4.02-3.98(\mathrm{~m}, 1 \mathrm{H}), 3.98-$ $3.90(\mathrm{~m}, 7 \mathrm{H}), 3.89-3.68(\mathrm{~m}, 26 \mathrm{H}), 3.61-3.38(\mathrm{~m}, 16 \mathrm{H}), 3.04-2.95$ $(\mathrm{m}, 2 \mathrm{H}), 1.77-1.57(\mathrm{~m}, 5 \mathrm{H}), 1.54-1.37(\mathrm{~m}, 3 \mathrm{H}), 1.36-1.18(\mathrm{~m}$, $42 \mathrm{H}) ;{ }^{13} \mathrm{C}$ NMR $\left(126 \mathrm{MHz}, \mathrm{D}_{2} \mathrm{O}\right) \delta 102.5,102.1,100.9,99.6,78.1$, 78.0, 77.6, 77.4, 72.2, 72.0, 71.8, 71.7, 71.4, 70.2, 70.1, 69.9, 69.4, 69.3, $69.2,68.7,67.5,39.4,28.1,26.6,22.5,16.8,16.7,16.5$; HRMS [M + $\mathrm{H}]^{+}$calcd For $\mathrm{C}_{89} \mathrm{H}_{154} \mathrm{NO}_{57} 2149.9211$, found 2149.9220 .

\section{ASSOCIATED CONTENT}

\section{S Supporting Information}

The Supporting Information is available free of charge on the ACS Publications website at DOI: 10.1021/acs.joc.7b02511.

${ }^{1} \mathrm{H}$ and ${ }^{13} \mathrm{C}$ NMR spectra of all new compounds (PDF)

\section{AUTHOR INFORMATION}

\section{Corresponding Author}

*E-mail: jcodee@chem.leidenuniv.nl.

\section{ORCID}

Herman S. Overkleeft: 0000-0001-6976-7005 Jeroen D. C. Codée: 0000-0003-3531-2138

\section{Notes}

The authors declare no competing financial interest.

\section{ACKNOWLEDGMENTS}

This work was supported by The Netherlands Organization of Scientific Research (NWO Vidi grant to J.D.C.). We thank F. Lefeber and K. Babu for their assistance with the NMR experiments, and F. Chiodo for his assistance with MALDITOF measurements.

\section{REFERENCES}

(1) Plante, O. J.; Palmacci, E. R.; Seeberger, P. H. Science 2001, 291, $1523-1527$.

(2) Seeberger, P. H. Acc. Chem. Res. 2015, 48, 1450-1463.

(3) Kröck, L.; Esposito, D.; Castagner, B.; Wang, C.-C.; Bindschädler, P.; Seeberger, P. H. Chem. Sci. 2012, 3, 1617.

(4) Hahm, H. S.; Schlegel, M. K.; Hurevich, M.; Eller, S.; Schuhmacher, F.; Hofmann, J.; Pagel, K.; Seeberger, P. H. Proc. Natl. Acad. Sci. U. S. A. 2017, 114, E3385-E3389.

(5) Schmidt, D.; Schuhmacher, F.; Geissner, A.; Seeberger, P. H.; Pfrengle, F. Chem. - Eur. J. 2015, 21, 5709-5713.

(6) Walvoort, M. T. C.; Volbeda, A. G.; Reintjens, N. R. M.; van den Elst, H.; Plante, O. J.; Overkleeft, H. S.; van der Marel, G. A.; Codée, J. D. C. Org. Lett. 2012, 14, 3776-3779.

(7) Naresh, K.; Schumacher, F.; Hahm, H. S.; Seeberger, P. H. Chem. Commun. 2017, 53, 9085-9088.

(8) Kandasamy, J.; Schuhmacher, F.; Hahm, H. S.; Klein, J. C.; Seeberger, P. H. Chem. Commun. 2014, 50, 1875-1877.

(9) Hahm, H. S.; Broecker, F.; Kawasaki, F.; Mietzsch, M.; Heilbronn, R; Fukuda, M.; Seeberger, P. H. Chem. 2017, 2, 114-124.

(10) Weishaupt, M. W.; Matthies, S.; Seeberger, P. H. Chem. - Eur. J. 2013, 19, 12497-12503.

(11) Walvoort, M. T. C.; van den Elst, H.; Plante, O. J.; Kröck, L.; Seeberger, P. H.; Overkleeft, H. S.; van der Marel, G. A.; Codée, J. D. C. Angew. Chem., Int. Ed. 2012, 51, 4393-4396.

(12) Volbeda, A. G.; Reintjens, N. R. M.; Overkleeft, H. S.; van der Marel, G. A.; Codée, J. D. C. Eur. J. Org. Chem. 2016, 2016, 52825293.

(13) Carapetis, J. R.; Steer, A. C.; Mulholland, E. K.; Weber, M. Lancet Infect. Dis. 2005, 5, 685-694.

(14) Cunningham, M. W. Clin. Microbiol. Rev. 2000, 13, 470-511.

(15) Kabanova, A.; Margarit, I.; Berti, F.; Romano, M. R.; Grandi, G.; Bensi, G.; Chiarot, E.; Proietti, D.; Swennen, E.; Cappelletti, E.; Fontani, P.; Casini, D.; Adamo, R.; Pinto, V.; Skibinski, D.; Capo, S.; Buffi, G.; Gallotta, M.; Christ, W. J.; Campbell, S. A.; Pena, J.; Seeberger, P. H.; Rappuoli, R.; Costantino, P. Vaccine 2010, 29, 104114

(16) van Sorge, N. M.; Cole, J. N.; Kuipers, K.; Henningham, A.; Aziz, R. K.; Kasirer-Friede, A.; Lin, L.; Berends, E. T. M.; Davies, M. R.; Dougan, G.; Zhang, F.; Dahesh, S.; Shaw, L.; Gin, J.; Cunningham, M.; Merriman, J. A.; Hütter, J.; Lepenies, B.; Rooijakkers, S. H. M.; Malley, R.; Walker, M. J.; Shattil, S. J.; Schlievert, P. M.; Choudhury, B.; Nizet, V. Cell Host Microbe 2014, 15, 729-740.

(17) Pozsgay, V.; Jennings, H. J. J. Org. Chem. 1988, 53, 4042-4052.

(18) Dhara, D.; Kar, R. K.; Bhunia, A.; Misra, A. K. Eur. J. Org. Chem. 2014, 2014, 4577-4584.

(19) Hahm, H. S.; Schlegel, M. K.; Hurevich, M.; Eller, S.; Schuhmacher, F.; Hofmann, J.; Pagel, K.; Seeberger, P. H. Proc. Natl. Acad. Sci. U. S. A. 2017, 114, E3385-E3389.

(20) Martin, C. E.; Weishaupt, M. W.; Seeberger, P. H. Chem. Commun. 2011, 47, 10260.

(21) Pozsgay, V. Carbohydr. Res. 1992, 235, 295-302.

(22) Pozsgay, V.; Brisson, J.-R.; Jennings, H. J. Can. J. Chem. 1987, 65, 2764-2769.

(23) Czechura, P.; Guedes, N.; Kopitzki, S.; Vazquez, N.; MartinLomas, M.; Reichardt, N.-C. Chem. Commun. 2011, 47, 2390-2392.

(24) Schmidt and co-workers have described an alternative approach in which the linker is first attached to the solid support, after which the remaining free carboxylates on the resin are methylated.

(25) Roussel, F.; Takhi, M.; Schmidt, R. R. J. Org. Chem. 2001, 66, $8540-8548$ 
(26) Crich, D.; Vinogradova, O. J. Org. Chem. 2007, 72, 3581-3584.

(27) Removal of the anomeric thiophenyl group from 18 was accompanied by partial migration of the C-2 CNPiv group to the anomeric position. Upon treatment of the resulting alcohol with the standard conditions for installation of the imidate group, compound 2 was obtained.

(28) Tesser, G. I.; Balvert-Geers, I. C. Int. J. Pept. Protein Res. 1975, 7, 295-305.

(29) For this synthesis, the reaction time for the glycosylation reaction was doubled $(60 \mathrm{~min}$ instead of $30 \mathrm{~min}$ ), and the amount of $\mathrm{H}_{2} \mathrm{NNH}_{2} \cdot \mathrm{AcOH}$ used for deprotection of the Lev group was increased to 8 equiv.

(30) Szpilman, A. M.; Carreira, E. M. Org. Lett. 2009, 11, 1305-1307. (31) Potter, R. G.; Hughes, T. S. Org. Lett. 2007, 9, 1187-1190.

(32) Huang, F.; Zhang, C.; Li, S.; Zhang, J.; Zhu, K.; Li, N. Org. Lett. 2007, 9, 5553-5556. 